\title{
Na marginesie recepcji literatury RFN... Polski odbiór Heinza Piontka
}

O ile udało się trafić na najwcześniejsze ślady recepcji, wydaje się, że Heinz Piontek pojawił się na łamach polskiej prasy z początkiem lat 60 . XX stulecia. Wszystko wskazuje na to, że po raz pierwszy wprowadził go do świadomości polskich czytelników Wilhelm Szewczyk, śląski działacz społeczny, polityczny i kulturalny, redaktor i publicysta, a zarazem niezrównany komentator i krytyk współczesnej literatury niemieckiej. Nim sportretował go w osobnym artykule w „Zaraniu Śląskim”, a później w podręcznikowej Literaturze niemieckiej $w X X$ wieku, informacje o poecie przekazywał kilkakrotnie w swoim cyklu publicystyczno-felietonowym Co robia Niemcy. Cykl, zapoczątkowany wcześniej na łamach katowickiej „Odry”, nb. redagowanej przez Szewczyka, od jesieni 1960 roku na parę dziesięcioleci znalazł swoje miejsce publikacji w „Życiu Literackim”. Właśnie w tekście, zatytułowanym Literackie fetysze odwetowców, 13.11.1960 roku, inaugurującym stały felieton w krakowskim tygodniku, autor poświęcił sporo miejsca „wschodnioniemieckiej nagrodzie literackiej”, przyznawanej przez „działającą w NRF instytucję rewizjonistyczną, zwaną Künstlergilde" (WISZ 1960a). (Wypada wspomnieć, że Co robiq Niemcy nie był w tym czasie jedynym felietonem Szewczyka, który inny swój cykl, Notatki i utarczki, ogłaszał w katowickiej „Trybunie Robotniczej”. Tam właśnie dwa tygodnie wcześniej ukazał się jego tekst właściwie na ten sam temat, nagrody Künstlergilde, gdzie wśród nagrodzonych w poprzednich latach wymieniony został również Piontek (por. WISZ 1960b)).

Szewczyk przedstawiał krótko dotychczasowych laureatów tej nagrody, zaczynając od najwcześniejszych: „Po raz pierwszy nagrodę przyznano w roku 1957. Otrzymali ją Heinz Piontek i Gerhart Pohl. Dwaj ci 
pisarze, należący do różnych formacji pokoleniowych, w różny sposób odpowiadali na polityczne zamówienie rewizjonizmu" (WISZ 1960a). Dalej charakterystyka dotyczyła pierwszego z nich:

Heinz Piontek, urodzony w roku 1925 na Opolszczyźnie i wywodzący się z tego samego pnia rodowego, z którego wyszedł znany pisarz Gustaw Freytag, w pierwszych swoich utworach poetyckich i prozatorskich zafascynowany jest jeszcze owym dziejowym fenomenem, jakim była utrata Śląska przez Niemcy; eksploatuje w swej twórczości po części własne i własnej swojej generacji przeżycia, bóle i rozczarowania polityczne, ale zawiera raczej filozoficzne, nie polityczne uogólnienia. Im więcej dojrzewa i krzepnie talent poetycki Piontka, tym rzadziej odzywa się w jego twórczości owa „śląskość”, pruska zuchowatość rozpływa się w melancholii i już tylko przeżycie krajobrazu śląskiego wiąże Piontka z krajem lat dziecinnych.

WISZ 1960a

Zaznaczając konieczność uproszczenia obrazu ${ }^{1}$, autor sytuował twórcę (niewątpliwie bardzo wysoko!) w konfiguracji literackiej RFN, a zarazem odnosił się do jego relacji z „kręgami rewizjonistycznymi”: „Dzisiaj Piontek należy do kilkuosobowej grupy najwybitniejszych poetów zachodnioniemieckich młodego, a właściwie średniego już pokolenia i na zamówienie polityczne odwetowców odpowiada bardzo rzadko, fascynując ich nadal swoją przynależnością rodową i regionalną" (WISZ 1960a). Piontkowi przeciwstawiał drugiego nagrodzonego („Inaczej z Gerhartem Pohlem"), którego postawę i twórczość - na podstawie uznawanych przez siebie kryteriów - również zwięźle omawiał.

Jak łatwo można zauważyć, publikacje Szewczyka, zwłaszcza dotyczące literatury i życia literackiego Niemiec współczesnych, podporządkowane były doraźnym ocenom politycznym, co też wyraźnie widać w omawianej publikacji. Autor poświęcił uwagę laureatom nagrody, podporządkowując wypowiadane opinie przyjętemu wartościowaniu. Nic zatem dziwnego, że w oczach Szewczyka nie znaleźli uznania ani Pohl, ani kolejni nagrodzeni: Edzard Schaper (1958), August Scholtis (1959), Horst Lange i polski pisarz emigracyjny Tadeusz Nowakowski (1960). Wśród nich właściwie tylko Piontek był twórcą, którego można było acz z pewnymi, niewielkimi w istocie, zastrzeżeniami - zaakceptować.

Zdobywający coraz większe uznanie w Republice Federalnej poeta pojawił się pobocznie w Szewczykowym cyklu również w roku następnym. W jednym z felietonów zajął się „Ślązakami, którzy, wywodząc

${ }^{1}$ Szewczyk deklarował: „Odnotowuję tu oczywiście generalną linię jego [H. Piontka - K.P.] rozwoju, pomijam utwory okolicznościowe” (WISZ 1960a). 
się z polskiej tradycji rodzinnej, wsiąknęli w niemieckość" (WISZ 1961). Następnie rozwijał to zagadnienie, przyjmując właściwy sobie sposób argumentacji:

O tym jednak, jaką rolę spełnić mają Ślązacy, którzy rozwinęli w sobie niemiecką świadomość narodową, zadecydowały i decydują nadal warunki polityczne. [...] jeśli taki utalentowany Ślązak nie spełni nadziei, jakimi obdarzają go odwetowcy, naraża się na wymówki, albowiem politykom odwetowym nie może po prostu pomieścić się $\mathrm{w}$ głowie, że pisarz pochodzący ze Śląska może odrywać się w swej twórczości od aktualnych „zadań wschodnich” narodu niemieckiego. Na takie wymówki naraził się już kilkakrotnie August Scholtis [...]. Na takie same wymówki naraził się Heinz Piontek, pochodzący z Kluczborka, jeden z najwybitniejszych współczesnych poetów zachodnioniemieckich, w którego twórczości tematyka śląska przekazywana jest coraz rzadziej i to w tonie elegijnym, a nie bojowo-nacjonalistycznym, jak by to odpowiadało politykom.

WISZ $1961^{2}$

Można dostrzec, że w tym czasie Szewczyk wprowadzał do swego cyklu Piontka jeszcze kilka razy, choć przeważnie mimochodem i przy okazji. Między innymi stawiał go wśród kontynuatorów liryki Wilhelma Lehmanna ${ }^{3}$. Innym razem, pisząc o licznych w Republice Federalnej nagrodach literackich, wyrażał zadowolenie, iż „pocieszającym zjawiskiem jest wyróżnianie młodych, przy czym nie brak wśród wielokrotnie na-

${ }^{2} \mathrm{O}$ zachodnioniemieckich literatach ze Śląska pisał Szewczyk, że „na ogół nie odgrywają oni pozytywnej roli w społeczeństwie niemieckim i - jak widać z praktyki politycznej w NRF - obarczają oni chętnie cały naród swoimi wschodnimi kompleksami, narzucają mu prymat treści politycznych, które nie mają nic wspólnego z pokojem" (WISZ 1960a). Twierdził, że „szczególną aktywność tego rodzaju wykazują na terenie NRF pisarze, którzy związani ze Śląskiem, zwłaszcza z Górnym Śląskiem, urodzeniem a także nadal węzłami pokrewieństwa z mieszkającym tu polskim odłamem rodzinnym - rozpętują w sobie niedobre, szowinistyczne moce, głosząc nienawiść do Polski. Każdy z tych pisarzy, od Alfonsa Hayduka po Arnolda Ulitza, to niejako przypadek kliniczny, którego zbadaniem winna się zająć nie tyle historia literatury, ile specjalny rodzaj inwigilacji psychologicznej" (WISZ 1960a). Jako przeciwstawny (i w pełni aprobowany) przykład przywołany został twórca również o śląskim rodowodzie Hans Marchwitza, tworzący w NRD, a także działający również po tej stronie niemieckiej granicy tytułowi trzej tłumacze literatury polskiej na język niemiecki: Viktor Mika, Wilhelm Tkaczyk i Henryk Bereska.

3 „Wilhelm Lehmann należy bowiem z całą swoją świetną twórczością poetycką do ogólnonarodowej literatury niemieckiej i tak jak w NRF uczniami jego są młodsi oraz starsi poeci, Karl Krolow, Heinz Piontek czy Günter Eich, w NRD do tego samego grona zaliczyć by można jednego z najlepszych poetów tego kraju, Petera Huchela" (WISZ 1962c). 
gradzanych piór postępowych" (WISZ 1962d), pośród których zauważał także Piontka, nagrodzonego już pięciokrotnie ${ }^{4}$.

Kiedy indziej, przedstawiając poezję Johannesa Bobrowskiego, Szewczyk zestawiał go z ,innym wybitnym poetą niemieckiej współczesności, także pochodzącym ze Wschodu, z lesistych krańców Opolszczyzny, z ziemi kluczborskiej" (WISZ 1962c). Dostrzegał, że - podobnie jak Bobrowski - „również i Piontek jest elegijny, również i on swoje przeżycie Wschodu przekazuje w słowach pełnych zadumy, że nastąpiło w dziejach narodu niemieckiego coś nieodwracalnego" (WISZ 1962c). Dalej stawiał (raczej ryzykowną, lecz motywowaną politycznie) tezę, że „ten smutek jest zrozumiałym ludzkim odruchem - jest to jednak mimo wszystko smutek optymistyczny" (WISZ 1962c), co uzasadniał za pomocą przeciwstawienia innej, nieakceptowanej twórczości:

Ani Bobrowski bowiem, ani też Piontek - tak głęboko odczuwający swój kraj młodości z jego narodowościową i duchową krzyżówką nie sięgają po nową zbroję i po nowy fałszywy bohaterski patos, jak to czynią, na przykład, „wschodniopruska” Agnes Miegel w swoich niezliczonych balladach lub - wybaczmy sobie proporcje - Hans Niekrawietz w swoich śląskich malowankach.

WISZ 1962c

Porównanie dwóch poetów niemieckiego Wschodu nie ograniczało się jednak tylko do tego. Szewczyk pisał: „Piontkowi jego ziemia kluczborska wydaje się czymś w rodzaju odległego, tajemniczego Tybetu. »Urodziłem się w Tybecie nad Odrą" - powiada. Jest to już mit tak daleki, że nie warto uwzględniać go w aktualnym wokabularzu politycznym” (WISZ 1962a). Wywód zmierzał do konkluzji: „Sarmacja Bobrowskiego nie jest nadodrzańskim Tybetem Piontka. Obaj jednak wiedzą, że nie ma powrotu. Stąd ich smutek i żal. Bobrowski czuje to głębiej, dlatego szuka pociechy w fakcie, że ziemia ta pięknieje, że żyją

4 „Böll otrzymał już osiem nagród literackich [...]; po pięć nagród otrzymali tacy pisarze, jak związani z Grupą 47, Ingeborg Bachmann, Ilse Aichinger, Günter Eich oraz pochodzący z Kluczborka na Opolszczyźnie poeta i prozaik Heinz Piontek" (WISZ 1962d).

${ }^{5}$ Przywołując określenie Piontka, metaforyzujące kraj jego pochodzenia, Szewczyk unika w tym wypadku niewygodnych sensów politycznych, które zdawały się wówczas czytelne, sprowadzając pojęcie Tybetu jedynie do egzotyki. Abstrahując od intencji Piontka, agresja wojsk chińskich w 1950 roku i wcielenie niepodległego dotychczas państwa do komunistycznych Chin, jak również exodus Tybetańczyków po antychińskim powstaniu 1959 roku do Indii nasuwałyby inne jeszcze aktualne skojarzenia, warte uwzględnienia „w aktualnym wokabularzu politycznym”. Szewczyk jednak przemilcza takie odczytanie. 
na niej ludzie, którzy wszystko, co w niej urodziwe, podniosą na nowo, wypieszczą i pokażą światu" (WISZ 1962a) ${ }^{6}$.

Pierwsza w Polsce osobna (i możliwie całościowa) prezentacja cenionego $\mathrm{w}$ Niemczech, a nieznanego $\mathrm{w}$ Polsce ${ }^{7}$ poety i prozaika dokonała się za sprawą tego samego autora w 1961 roku w regionalnym kwartalniku o charakterze (popularno)naukowym, organie Śląskiego Instytutu Naukowego. (Uprzedzając dalsze obserwacje, dodać można, że pozostanie ona na długie lata odosobnionym, jedynym właściwie tak wnikliwym portretem niemieckiego twórcy w całej jego polskiej recepcji!). W obszernym tekście, zatytułowanym Heinz Piontek, czyli objawienie talentu, Wilhelm Szewczyk kreślił drogę życiową i artystyczną młodego, utalentowanego i obiecującego pisarza zachodnioniemieckiego, wywodzącego się ze Śląska. W „Zaraniu Śląskim” pisał o nim:

Zaliczony został od razu do grupy najwybitniejszych poetów zachodnioniemieckich, których liczba nie jest aż tak wielka, jak by to wynikało z licznych publikacji książkowych, i nie przekracza dziesięciu nazwisk w czołówce. Uznanie to przekroczyło granice Niemieckiej Republiki Federalnej; utwory Piontka przetłumaczone zostały, jak dotąd, na pięć języków zachodnioeuropejskich. Również w Niemieckiej Republice Demokratycznej pokwitowano wysoką rangę literacką Piontka, uwzględniając jego życiorys i twórczość w pierwszym powojennym Deutsches Schriftstellerlexikon von den Anfängen bis zur Gegenwart (Weimar 1960). [...] Jeśli się zważy, że większość poważnych analitycznych prac o twórczości Piontka ukazała się po opublikowaniu przez niego zaledwie dwóch tomów wierszy [...], to zrozumiałe stanie się również nasze zainteresowanie dla tego fenomenu poetyckiego, jak go niektórzy nazywają, dla talentu, który, zrodzony na Górnym Śląsku, stał się manifestacją nowej poezji niemieckiej.

SZEWCZYK 1961: 811

Szewczyk nie taił przy tym intencji, jakimi się kierował w swoim zainteresowaniu poetą:

${ }^{6}$ To zestawienie dwóch niemieckich pisarzy, reprezentujących piśmiennictwo NRD i RFN, oraz ich ocena wpisują się jak najbardziej w Szewczykowe wartościowanie dokonań literatury wschodnio- i zachodnioniemieckiej. Tydzień po tym felietonie publicysta pisał na tych samych łamach: „Ta literacka specyfika [NRD - K.P.] jest czymś tak osobliwym na obszarze całej współczesnej literatury języka niemieckiego, że domaga się pełniejszej, dokładniejszej uwagi - na równi z interesującymi zjawiskami rozwojowymi z terenu NRF. Nie tylko zresztą uwagi - domaga się również aprobaty, co wynika z ogólnej sytuacji politycznej" (WISZ 1962b).

7 Jak najbardziej zasadne było stwierdzenie, że „Piontek jest w Polsce poetą nieznanym" (SZEWCZYK 1961: 814). 
Heinz Piontek zajmuje nas nie tylko jako osobowość twórcza czy jako oryginalna organizacja artystyczna. Wielokrotnie nagradzany uzyskał także wyróżnienie jury tzw. Ostdeutscher Schrifttumspreis der Künstlergilde Esslingen [...]. Często także, przeważnie bez istotnego politycznego powodu, chlubią się nim publicyści pism odwetowych, odwołując się do jego rodzimości śląskiej, jakby ona jedynie decydowała o czyjejś przydatności dla propagandy rewizjonistycznej.

SZEWCZYK 1961: 810

Z tej perspektywy krytyk przyglądał się utworom Piontka - jako znamienny przykład omawiał wiersz Rozproszeni ${ }^{8}$, który cytował we własnym tłumaczeniu, oraz opowiadaniom z tomu Vor Augen (1955). W konkluzji formułował następujące uogólnienia (z końcowym „generalnym wnioskiem"):

Piontek jest piewcą zagłady wszystkiego, co niemieckie, na ziemiach przejętych przez Polskę, na Śląsku Opolskim, na swojej rodzinnej ziemi kluczborskiej, leżącej pod niebem ,podmalowanym sepią i gąbczastą ochrą”. [...] Burzy doszczętnie legendę o „bezpiecznej, kwitnącej krainie" pod władzą niemiecką. [...] Ten świat skończył się definitywnie, świat niemiecki, przetrząśnięty przez pisarza tak dokładnie, że nikt po nim nie ma już prawa mówić o śląsko-niemieckiej sielance, o wielkości misji dziejowej i tym podobnych nacjonalistycznych idolach. Śląsk odsunięty został w wyobraźni poety w krainę mrocznych, ponurych mitów, gdzie powietrze staje się coraz cieńsze dla tych, którzy nie umieli pojąć nadchodzącej lub istniejącej już przemiany.

SZEWCZYK 1961: 818

Rok później tekst, nieco przeredagowany, rozszerzony i uzupełniony, wszedł do podręcznikowego opracowania Szewczyka Literatura niemiecka $w$ XX wieku. W oczach prominentnego germanisty książka Szewczyka uznana została za ,jedno z największych wydarzeń rynku wydawniczego końca 1962 roku" (SzYrocki 1963c: 694). Wypowiadający te słowa Marian Szyrocki, który przygotowywał w tym czasie własną syntezę literatury niemieckiej, podnosił dotychczasowe popularyzatorskie zasługi krytyka w tej dziedzinie. Przede wszystkim jednak oceniał jego ostatnie dokonanie, starając się określić stanowisko metodologiczne autora:

${ }^{8}$ Szewczyk dokładnie lokalizował utwór, pisząc o „wierszu pt. Die Verstreuten z cyklu tak samo nazwanego, który otwiera wiersz o zatonięciu Scharnhorsta, z tomu Wassermarken" (SzEwCZYK 1961: 814). Parę stron wcześniej zostały wymienione wszystkie opublikowane do tej pory książki Piontka, w tym również wspomniany tom poezji z 1957 roku (SzEwCZYK 1961: 811). 
[...] praca Szewczyka ma znaczenie pionierskie i zasługuje na szczególną uwagę, a to tym bardziej, że na Zachodzie ukazało się w latach ostatnich szereg książek traktujących o literaturze naszych zachodnich sąsiadów. Są one pisane z pozycji jak najbardziej różniących się od historycznorozwojowej metody Szewczyka. Wystarczy tutaj wymienić choćby dwutomową historię niemieckiej literatury współczesnej Duwego czy szkic Horsta. Reprezentują oni modną dzisiaj w literaturoznawstwie zachodnim metodę zwaną metodą interpretacji. [...] Historycznorozwojowa metoda Szewczyka natomiast stanowi antytezę tego kierunku i jest dla autora punktem wyjścia do przeprowadzenia oceny ideologicznej pisarza ${ }^{9}$.

Piontek pojawił się także w innych miejscach opracowania. Młodego, utalentowanego i obiecującego pisarza zachodnioniemieckiego, pochodzącego z utraconego przez Niemcy Kluczborka, Szewczyk umieścił w części drugiej (Szkice do sytuacji), w której rozprawiał się z „tematami odwetu”. Na tym tle charakterystyka Piontka wypadała bezsprzecznie dodatnio. Warto tę ocenę przywołać:

Heinz Piontek jest najwybitniejszym zjawiskiem literackim, które zwykło się łączyć z literaturą odwetową. Ale analiza twórczości Piontka [...] dowodzi, jak niełatwo czasem określić jednoznacznie charakter ideowy literatury o nurcie odwetowym, jak subtelnymi często środkami posługuje się ona, jak - w końcu - niejedno uczciwe zamierzenie pisarskie, pozbawione tzw. politycznych Hintergedanken, wykorzystywane bywa bezpardonowo przez polityków odwetowych. Niewątpliwie istnieje w twórczości Piontka obfita substancja wschodnioniemiecka, niewątpliwie twórczość jego z tych przeżyć wyrosła i w pierwszej swojej fazie służyła ich konwencjonalnemu odbiciu. Ale wielki talent Piontka, jego kontakt z szeroką myślą artystyczną współczesnych Niemiec Zachodnich - pozwolił mu złamać obręcz prowincjonalizmu, którą już wokół jego dzieła literackiego zaciskano. Wyrwawszy się poza krąg nakazów i postulatów ziomkowskich, Piontek przestał być typowym piewcą „wschodnioniemieckiej ojczyzny” w sensie odwetowym, stając się tym w poezji, czym Siegfried Lenz w prozie.

SZEWCZYK 1962: 206

W części trzeciej (Szkice do portretów) znalazł się znany już artykuł Heinz Piontek, czyli objawienie talentu, nieznacznie przeredagowany, lecz

9 Mimo przeważnie aprobatywnego tonu wrocławski germanista formułował również pewne zastrzeżenia. Dostrzegał, że „Szewczyk pisze w sposób niezwykle żywy, barwny, a czasem też agresywny. Niekiedy jednak jego błyskotliwe sformułowania budzą w tak poważnym dziele pewne wątpliwości. Szczególnie wówczas, gdy postać pisarza, ceniona przez wielu wybitnych historyków literatury i krytyków, nie znalazła uznania w oczach Szewczyka" (SzYrocki 1963c: 694-695). 
istotnie uzupełniony o znaczący fragment, dotyczący głównie utworu dramatycznego, zrealizowanego i nadanego w październiku 1961 roku jako słuchowisko radiowe, a w następnym roku opublikowanego osobno pt. Weisser Panther (Biała pantera), którego urywek (w tłumaczeniu Szewczyka) wszedł do szkicu.

Również w zamieszczonym na końcu słowniku pisarzy niemieckich Piontek miał swoje hasło. Zwięzła prezentacja zawierała najważniejsze informacje o jego drodze życiowej i aktywności twórczej. Autor hasła wymieniał wszystkie dotychczasowe tomy poetyckie (łącznie z ostatnim, Mit einer Kranichfeder, opublikowanym w roku wydania książki Szewczyka!), informował też o eseistyce (tom Buchstab, Zauberstab), „mistrzowskich krótkich opowiadaniach w książce Vor Augen” oraz „przekładach z Johna Keatsa” (Szewczyk 1962: 357).

Już u Szewczyka znalazły się próbki twórczości wywodzącego się ze Śląska autora w przekładzie na język polski: przetłumaczony w całości „poemat narracyjny” Rozproszeni (Die Verstreuten), krótki fragment opowiadania Abends im Oderried, pochodzącego z debiutanckiego tomu opowiadań Vor Augen, oraz urywek słuchowiska Biała pantera (Weisser Panther), w którym

Piontek udramatyzował [...] na nowo grecki mit o Pentesilei, królowej Amazonek, i Achillesie, jej zabójcy. Pentesileją jest tutaj Niemka, Judith von Rüstow, Achillesem zaś kapitan armii radzieckiej, Achilla Petrowicz Tuganow. Rzecz dzieje się na dwóch planach chronologicznych: współcześnie - w pewnym zachodnioniemieckim konwikcie i w roku 1945 - na przedpolu oblężonego Wrocławia. Achilles-Tuganow nie zabija - jak to było w micie greckim - swej ukochanej Pentesilei-Judyty.

SZEWCZYK 1962: 312

To ostatnie dzieło, omówione dość dokładnie przez Szewczyka, dostarczało argumentów, by potraktować „rozwój ideowy pisarza” za godny uznania i docenienia przez polskich czytelników:

Również i ten utwór jest więc odżegnaniem się Piontka od tych wszystkich ziomków, którzy nadal biją w nieostygłe tarabany. Na tle produkcji literackiej, gloryfikującej obronę „Festung Breslau”, Biała pantera jest szlachetną ofertą, jest zarysem interesujących pięknych intencji, całkowicie wolnych od nacjonalizmu. Piontek sięga po mity, są to jednak mity kształcące uczucia godne prawdziwego człowieka. Można o nim rzec słowami narodu, którego kultura duchowa patronuje jego pracy: Non ad genus, sed ad mores partinet. 
W tym samym czasie wprowadził Piontka jako reprezentatywnego zachodnioniemieckiego twórcę Aleksander Rogalski w swojej pracy Niemiecka Republika Federalna. Fakty, konfrontacje, opinie, w której sporo miejsca poświęcił sprawom kultury i literatury. W rozdziale o Życiu literackim $w$ NRF, w jednym z podrozdziałów, przedstawiał „sytuację młodych pisarzy”, w której firmy wydawnicze „uciekają się do różnych sposobów, byle tylko zachęcić młodych autorów do pisania” - „udzielają stypendiów, rozpisują konkursy, ustalają nagrody" (RogALSKI 1962: 280). Jedną z form wsparcia materialnego udzieliło wydawnictwo Bertelsmanna w Gütersloh. I tak ,beneficjentami funduszu literackiego Bertelsmanna byli np. autorzy w rodzaju Heinza Piontka, H. Lipińskiego-Gottersdorfa [sic!], A.A. Scholla i L. Sieversa" (Rogalski 1962: 282). Obok tej drobnej wzmianki Piontek doczekał się krótkiej charakterystyki w rozdziale o zachodnioniemieckiej poezji. Właśnie jego i Karla Krolowa Rogalski uznał za „dwóch najbardziej reprezentatywnych liryków zachodnioniemieckich". Konstatując w powojennej poezji wyraźny wpływ Gottfrieda Benna, u nich dostrzegał „akcenty pewnej oryginalności”.

Młodszy o całe dziesięć lat od Krolowa, Hans [sic!] Piontek (urodził się w r. 1925) czerpie podniety nie tylko u Benna, ale także u T.S. Eliota, Rilkego i Ezry Pounda. Jego pole widzenia jest węższe niż u Krolowa, za to jego wiersze odznaczają się dużą intensywnością. Jednocześnie są one bardziej „literackie”, to znaczy - nie tyle wypływają z przeżyć osobistych, ile z wrażeń odniesionych z literatury. Dlatego też nieraz określa się je jako „aleksandryniczne”.

RogALSKI 1962: 329

Zwraca uwagę, że Rogalski poetycką twórczość Piontka - z jednej strony - stawia wśród „szczytowych osiągnięć” liryki zachodnioniemieckiej. Z drugiej strony - w odróżnieniu od Szewczyka - w zasadzie zupełnie eliminuje kwestię jego śląskiego rodowodu (w jego prezentacji nie pada nawet miejsce urodzenia poety), sytuując twórczość Piontka w wymiarze uniwersalnym, bez jakichkolwiek odniesień regionalnych.

Śląski działacz i literat kierował w tym czasie szczególną uwagę na tendencje „rewizjonistyczne”, obserwowane w piśmiennictwie RFN, przeciwstawiając im twórców wolnych od podobnych inklinacji. Do tego wątku chętnie wracał w swoim cyklu Co robia Niemcy. W lipcu 1964 roku wypowiadał następującą opinię:

Zadziwiające wprost, jak wielu pisarzy niemieckich, zarówno po tej, jak i po tamtej stronie Łaby, wywodzi się z byłego pogranicza niemiecko-polskiego, z Górnego Śląska i Nadodrza. O ile większość z tych, 
którzy wybrali Niemiecką Republikę Federalną, nie pozbyła się nacjonalistycznych uprzedzeń wobec Polaków lub wręcz działa w nurcie odwetowym, w NRD z różnych powodów politycznych, a także osobistych stanowią oni konstruktywną wartość ideową. Oczywiście i w RFN nie brak wyjątków. [...] Heinz Piontek, 1925, z Kluczborka, znakomity poeta i nowelista, okazyjnie tylko i to w formach refleksyjno-lirycznych porusza tematykę byłego pogranicza.

WISZ 1964

Innym razem, pod koniec sierpnia 1965 roku, felietonista czynił kolejne spostrzeżenie na ten temat:

Wybitni pisarze, urodzeni na terenach za Odrą i Nysą Łużycką, nie nadają się prawie wcale do prezentacji w takich wydawnictwach [związanych z „kręgami ziomkowskimi” - K.P.], gdyż albo (jak Günter Grass) w swoich wypowiedziach publicystycznych zburzyli mit „konieczności powrotu na ziemie utracone", albo (jak Heinz Piontek) odeszli od tematyki wschodniej, przenosząc ją w sferę uogólniających medytacji, pozbawionych ostrza aktualnej polityki, nienadających się do krzepienia ducha i do konstruowania nowych, nierozumnych nadziei.

WISZ 1965

W szczególności życzliwa, wręcz entuzjastyczna prezentacja Szewczyka (zarówno w osobnym artykule, jak i w licznych wzmiankach w publicystyce z cyklu Co robia Niemcy) powinna była zachęcić do szerszego udostępnienia twórczości Piontka w tłumaczeniu na polski. Tak się jednak nie stało i kolejne utwory, do pewnego momentu tylko poetyckie, wprowadzane były rzadko, wybiórczo i nieregularnie. W połowie lat 60. przekład jednego wiersza zachodnioniemieckiego twórcy sporządził Florian Śmieja, pochodzący również ze Śląska emigracyjny poeta, hispanista i tłumacz, związany z londyńską grupą Kontynenty. Positek robotników drogowych (Das Mahl der Straßenwärter z wydanego w 1953 roku tomu Die Rauchfahne ${ }^{10}$ ) ukazał się najpierw w katowickich „Poglądach”"11, a nieco później w wychodzącym na emigracji kwartal-

10 Przy ustalaniu tytułów oryginalnych oraz publikacji Piontka użyteczna okazała się bibliografia Martina HolLENDRA (2000).

11 Wiersze poetów niemieckich. „Poglądy” (1-15.10.) 1965, nr 19, s. 8. Utwory Heinza Piontka i Güntera Grassa tłumaczył Florian Śmieja, pozostałe, autorstwa Petera Huchela, Paula Celana i Marianne Colin - Tadeusz Hołuj. Można zadać pytanie, w jaki sposób przekład ten trafił na łamy „Poglądów”. Mimo że emigrant Śmieja odwiedzał kraj. Jak podawał: „Moje pierwsze wyjazdy z emigracji do Polski prowadziły do Katowic do Wilhelma Szewczyka (1916-1991), który urzędował w centrum miasta w redakcji czasopisma »Poglądy «" (ŚMIEJA 2012: 17). Dodawał także: „Zachowałem jego [W. Szewczyka - K.P.] Literaturę niemieckq $w$ XX wieku z wczesną dedykacją na wyrost: »Panu Florianowi Śmieji z wieloma serdecznościami, jako znakomitemu uczonemu i poe- 
niku „Oficyna Poetów”12 (wraz ze stosunkowo obszerną notą tłumacza o autorze, którą warto tutaj przytoczyć:

HEINZ PIONTEK. Urodził się w 1925 r. w Kluczborku na Śląsku Opolskim. Próbował różnych zawodów: był kamieniarzem, robotnikiem na budowie, agentem handlowym. Studiował potem germanistykę, filozofię i historię sztuki. Następnie zaczął współpracować z prasą i radiem. Zaliczany do najwybitniejszych liryków powojennych, $\mathrm{w}$ wierszach swoich $\mathrm{i} \mathrm{w}$ prozie nie zapomina o kraju pochodzenia. Błąka się on w jego jaźni odrealniony i zmitologizowany, ale stanowi skuteczną odtrutkę na łatwy optymizm i wszelkiego rodzaju ciągotki nowego otoczenia. Dlatego to potrafi poeta powiedzieć, że pisać dla epoki, to znaczy przeciw epoce. Stratę łatwego poklasku w tym czy innym obozie ideologicznym kompensuje spokojna głębia wyzierająca z jego utworów. Poezje: Die Furt (1952), Die Rauchfahne (1957), Mit einer Kranichfeder (1962).

ŚMIEJA 1967: 32

Dobrze dla zachodnioniemieckiego autora rozpoczęta dekada lat 60 . pozwoliła po raz pierwszy zaprezentować go polskiemu odbiorcy w wydaniu książkowym, tym razem jako prozaika. W 1966 roku w warszawskim wydawnictwie Czytelnik ukazał się tom opowiadań Gorace kasztany (Kastanien aus dem Feuer) ${ }^{13}$. Dodać można, że książka opublikowana została w niezbyt wysokim jak na ówczesne warunki nakładzie (5280 egzemplarzy) i w skromnej szacie graficznej. Zbigniew Pędziński, którego recenzja wydrukowana została pośmiertnie, notował w związku z tym:

Gorące kasztany, niewielki objętościowo zbiór opowiadań, dzięki któremu większość czytelników zetknie się po raz pierwszy z nazwiskiem

cie, autor Wilhelm Szewczyk. Katowice, 19.07.65 " (ŚMIEJA 2012: 17-18). Zauważyć można, iż data cytowanej dedykacji nieznacznie poprzedza publikację wiersza Piontka właśnie w „Poglądach”.

12 Dla londyńskiej „Oficyny Poetów” (maj 1967, nr 2) Florian Śmieja przygotował próbkę współczesnej liryki niemieckiej, umieszczając we własnym przekładzie wiersze Hansa Magnusa Enzensbergera, Güntera Grassa, Bertolta Brechta i Heinza Piontka. Wybór był niewielki i cokolwiek przypadkowy, warto jednak docenić tę publikację, ponieważ w prasie emigracyjnej rzadko pojawiały się tłumaczenia z literatury (a zwłaszcza z poezji) niemieckiej, szczególnie współczesnej. Charakter wydawanego w latach 1966-1980 w Londynie przez Czesława Bednarczyka kwartalnika, w którym bogaty był dział przekładów, umożliwiał tego typu prezentację. W innych polskich pismach emigracyjnych, nawet o literackim nachyleniu, zdarzało się to wyjątkowo rzadko.

${ }^{13} \mathrm{Na}$ marginesie można zauważyć, że zaskakująco ta polska publikacja H. Piontka pominięta została w obszernym, przydatnym i w sumie dość starannie przygotowanym zestawieniu Jacka S. BuRASA (1996). 
jednego z najciekawszych prozaików i poetów NRF, nie jest, nawet jak na nasze stosunki, zbyt imponującą edytorsko wizytówką literacką. Kilka jakby wyciętych $\mathrm{z}$ dagerotypu czarno-białych sylwetek mężczyzn na obwolucie, parę tak zwięzłych, że aż czyniących wrażenie rzuconych od niechcenia uwag o pisarzu na jej skrzydełku - oto wszystko, co polski wydawca uczynił dla uatrakcyjnienia Goracych kasztanów i spopularyzowania Heinza Piontka: pisarz musi bronić się sam, własną i tylko tą spolszczoną twórczością, a wiadomo, jak charakterystyczną idiosynkrazją obdarzają nasi czytelnicy wszelkie tomy nowelistyczne na półkach księgarskich i bibliotecznych.

PęDZIŃsKi 1967

Recenzent gdańskich „Liter” przeciwstawiał się rutynowemu potraktowaniu tej wydawniczej nowości, bo „przecież Gorace kasztany są inne, podobnie jak różny od stereotypu zachodnioniemieckiego pisarza wydaje się ich autor" (PęDZiński 1967).

Przekład był dziełem Zofii Jaremko-Pytowskiej, tłumaczącej z literatury francuskiej (między innymi H. Barbusse'a, R. Martina du Garda, F. Mauriaca, Vercorsa) i niemieckiej (między innymi A. Seghers, A. Zweiga, P. Schallücka, J. Bobrowskiego), w tym czasie także recenzentki przekładów z literatur obcych, stale współpracującej z „Nowymi Książkami”. Niestety, wyjątkowo tylko opinie wyrażane o wydanej w Polsce książce niemieckiego autora dotyczyły efektu pracy translatorskiej. Lapidarną, jednozdaniową (i w sumie dość zdawkową) ocenę wypowiedział w swojej recenzji jedynie Zbigniew Żabicki: „Przekład Zofii Jaremko-Pytowskiej pełen elegancji, a przy tym oszczędny i celny w doborze słowa" (ŻABICKI 1967: 37). Warto zwrócić uwagę, że tytuł jednego opowiadania w polskiej wersji został zniekształcony; przypuszczać można, że nie z winy tłumacza, ponieważ ewidentna pomyłka mogła powstać w wyniku przeoczenia na etapie opracowania redakcyjnego albo późniejszego składu drukarskiego. Przedostatnie w polskim wydaniu opowiadanie zatytułowano Cieniste krzewy, natomiast oryginalny tytuł Dornbüsche należałoby przełożyć oczywiście jako Cierniste krzewy. (Ten literowy błąd, jednakże zmieniający istotnie sens tytułu, obecny jest i w nagłówku opowiadania, i w spisie treści tomu).

Jak się okaże, Gorace kasztany pozostaną na długie dziesięciolecia jedyną książką Piontka wydaną w Polsce. Tom wywołał pewien - uznać można, że dość typowy i raczej przeciętny (jak w przypadku jednej z licznych nowości wydawniczych) - rezonans prasowy. Właściwie każdy z polskich recenzentów czytał opowiadania Piontka inaczej, co może świadczyć o tym, że lektura nie była jednoznaczna, a odbiór oczywisty. Mimo że opinie były podzielone, niemal wszyscy wyrażali przekonanie, że mają do czynienia ze szczególnym zjawiskiem, jakim jest dla 
polskiego odbiorcy współczesna literatura niemiecka. Odnosił się do tego przy okazji wydanych w Polsce w 1966 roku: powieści Barbary König Żwir (Kies), Martina Walsera Matżeństwa w Ludwigsburgu [sic! - właśc. ...w Philippsburgu - K.P.] (Ehen in Philippsburg), Güntera Seurena Rezerwat (Das Gatter) oraz opowiadań Piontka, Wacław Sadkowski w „Trybunie Ludu”, organie prasowym rządzącej partii komunistycznej, wypowiadając opinię, że

[...] trudno [...] być pisarzem niemieckim - nie ma tematu, nie ma pokolenia, które uwalniałoby go od historycznej weryfikacji. Co prawda, każdemu pisarzowi utalentowanemu, każdemu pisarzowi, którego traktujemy poważnie, stawiamy wymagania podobne: zawsze zastanawiamy się, w jakim stopniu dotarł do najistotniejszych problemów i konfliktów swego społeczeństwa, jego historycznego losu. Nie jest naszą winą, że losy Niemiec i Niemców wypełniły się materią najbardziej skomplikowaną i najgłębiej dla świata dramatyczną. Nie za naszą sprawą stosunek do niej określa stopień dojrzałości i uczciwości pisarzy niemieckich.

SADKOWSKI 1966

Charakteryzując autora na podstawie omawianego tomu Gorace kasztany, recenzent czynił następujące, dość zresztą ogólnikowe spostrzeżenia:

Heinz Piontek [...] dysponuje sprawnym warsztatem analitycznym, trafnie wnika w wewnętrzny, psychologiczny mechanizm człowieka i zręcznie doprowadza swą analizę do nieoczekiwanych point, ujawniających jego wewnętrzne sprzeczności: jego nowele mają charakterystyczny dla współczesnej prozy ton „pytająco-sygnalizujący”, wolny od rozstrzygnięć i konkluzji, pozostawiający czytelnikowi do przemyślenia sprawy nierozstrzygnięte, otwarte.

SADKOWSKI 1966

W „Nowych Książkach”, w obszernej (i znacznie wnikliwszej niż poprzednia) recenzji, Zbigniew Żabicki zastanawiał się nad oceną wartości literackiej tej prozy. Swoje uwagi zaczynał od pochwał: „Heinz Piontek jest pisarzem kulturalnym. Nawet niezwykle kulturalnym. Gdyby to był polski debiutant - napisałbym o nim bardzo przychylnie, co najwyżej z lekka tylko utyskując nad pewną staromodnością jego prozy" (ŻABICKI 1967: 36). Po czym konkretyzował spostrzeżenia:

Ale Piontek nie jest Polakiem [...] i nie jest debiutantem. [...] tak jak pisze Piontek, pisze u nas legion. I to na wszystkich szczeblach drabiny pokoleń, zasług i rang literackich. Liryzm, ale i wielka oszczędność słowa, sprawiająca, iż niektóre epizody przypominają rysunki 
kreską; narrator - jeśli tylko sam nie jest bohaterem utworu, a niekiedy nawet i wówczas - wszechwiedzący, obiektywistyczny, choć równocześnie umiejący nasycić swą opowieść tajonym sentymentem; konstrukcja nowelistyczna - bezbłędna, szybko i dramatycznie wiodąca do ostro zarysowanej puenty, koncentracja fabularna - wzorowa, skoro niemal każda nowela prezentuje jakąś jedną znamienną sytuację, jakieś jedno charakterystyczne zachowanie się postaci, skoro każda w jednym epizodzie potrafi zsyntetyzować (lub przewartościować, jak w Bramie na świat [Das Tor zur Welt]) postawę wyróżniającą danego bohatera.

Słowem, proza Piontka okazuje te wszystkie walory, jakie zwykliśmy wiązać z poetyką klasycznej noweli. Jeśli do tego dodamy jeszcze, że autor jest niezłym psychologiem, który w analizę zachowań ludzkich potrafi wpleść dyskretnie metaforę biologistyczną [...] i świetnym malarzem krajobrazu, czasem zręcznie animizującym czy nawet antropomorfizującym kreślone przez siebie pejzaże [...] - będziemy wówczas mieli odnotowany niemal komplet zalet, nadających opowiadaniom Piontka bezspornie wysoką wartość literacką.

ŻABICKI 1967: 36

W toku omówienia jednak wątpliwości recenzenta narastały,

[...] albowiem głównym i niemal jedynym bohaterem utworów Piontka jest znany nam doskonale, szczególnie z naszej „młodszej” prozy - nieudacznik: człowiek wrażliwy, ale bez tzw. „pionu”; pechowiec, którego pech kryje się głównie w nim samym; osobnik nieumiejący ułożyć sobie życia, niepogodzony ani ze sobą, ani też z rzeczywistością, notabene, przedstawianą przez pisarza na ogół w wymiarach „małego realizmu”.

ŻABICKI 1967: 36

W końcu Żabicki stawiał pytanie o zasadność opublikowania Goracych kasztanów w Polsce: „Czy wydanie jego [H. Piontka - K.P.] książki $\mathrm{u}$ nas było niezbędne, zwłaszcza w sytuacji, gdy - ciągle, jak przed laty - nie mamy nadal opublikowanych przekładów Ameryki Kafki, Człowieka bez właściwości Musila, liryki Benna, ba! Ulissesa i Finnegan's Wake Joyce'a czy całej twórczości Henry Millera?” (ŻABICKI 1967: 37). Udzielona odpowiedź była ostrożna: „Zapewne nie; ale z pewnością było pożyteczne. Zarówno dla zdobycia pewnej orientacji we współczesnej literaturze NRF, jak i dlatego, że dzięki temu przyswoiliśmy sobie parę urywków dobrej prozy" (ŻABICKI 1967: 37).

Włodzimierz Maciąg na łamach „Życia Literackiego”, recenzując kilka wydawniczych nowości, książek z literatur zachodnich tłumaczonych na polski, charakteryzował i oceniał również prozę niemieckiego autora: 
Opowiadania Piontka mają charakter na wskroś współczesny, do wspomnień wojennych odwołują się rzadko [...], wojna jako taka i sprawy hitleryzmu autora nie inspirują - i to właśnie wydaje mi się interesujące. Czym bowiem żyje młody autor niemiecki - jako pisarz - jeśli nie sięga do tamtych spraw? Obcością, jaka istnieje między ludźmi i jaka rządzi wzajemnymi stosunkami. [...] Piontek szuka sobie bohaterów zupełnie innego pokroju, ludzi z głębokiej prowincji, ludzi nietkniętych jeszcze newrozami nowoczesności. Ta obcość, o jakiej mówi autor, rodzi się na innym planie, jest po prostu formą samotności jako trwałej, nieprzezwyciężalnej właściwości życia. Ironią opowiadań jest łączenie tych stanów wewnętrznych z miłością, kobiety i mężczyźni z tych opowiadań dopiero wówczas dostrzegają swoją samotność, kiedy w życie ich wkracza erotyka i jej pobudzające pulsacje.

MACIĄG 1967

Krytyk postawę pisarską Piontka odnosił - podobnie jak nieco wcześniej Zbigniew Żabicki - do zjawisk obserwowanych niedawno w literaturze polskiej, pisząc:

Przypomina mi to bardzo naszą młodą prozę sprzed paru lat. Piontek nie jest wprawdzie tak wylewny ani tak rozjątrzony swymi spostrzeżeniami, ale Piontek także wie, że stan nieświadomości ma swoje zalety, że dobrze jest być dzieckiem i nie trzeba się spieszyć do wydzierania dorosłym ich sekretów. Bo kiedy się je pozna, a zwłaszcza kiedy się je przeżyje - wchodzi się w świat powikłany i nieobliczalny, który budzi grozę i żadnej harmonii wewnętrznej nie obiecuje.

MACIĄG 1967

We wrocławskiej „Odrze” Jerzy Pluta zauważał, że „Piontek swoją wysoką rangę we współczesnej literaturze niemieckiej zawdzięcza twórczości poetyckiej. Jednak czytelnik polski rozpoczyna kontakt z twórczością Piontka od opowiadań, które są niejako marginesem jego twórczości. Tak więc obecna konfrontacja nie może być pełna" (PLUTA 1967: 84). Odnosząc się do treści zawartych w Gorących kasztanach, wrocławski prozaik i krytyk odkrywał ukrytą warstwę, ,podteksty”:

Pozornie Piontek koncentruje się na sprawach miłości, samotności i konfliktów małżeńskich. Łatwo także zauważyć, że opowiadania są całkowicie pozbawione tła społeczno-obyczajowego, czasem tylko nazwiska i nazwy miejscowości wskazują, iż akcja dzieje się w Niemczech [...]. Z drugiej jednak strony podteksty „kwestii niemieckiej” są jednoznaczne. Opowiadania dotyczą pewnych stanów i sytuacji psychologiczno-moralnych, charakterystycznych (a potwierdza to publicystyka i socjologia) dla okresu „cudu gospodarczego” w NRF: braku „egzaminów wewnętrznych”, powierzchowności uczuć, tęsk- 
not do powierzenia „wodzom” odpowiedzialności za siebie i społeczeństwo.

Pluta 1967: 84

Więcej można było się spodziewać po ocenach germanistów, znacznie lepiej zaznajomionych z problematyką literatury niemieckiej niż jej przygodni recenzenci, nawet $\mathrm{z}$ akademickimi, choć przeważnie polonistycznymi, kompetencjami (Zbigniew Żabicki i Zbigniew Pędziński byli pracownikami Instytutu Badań Literackich Polskiej Akademii Nauk, Włodzimierz Maciąg uzyskał doktorat na Uniwersytecie Jagiellońskim, kilka lat później dysertację doktorską na Uniwersytecie Wrocławskim obronił także Jerzy Pluta, po wyjeździe z Polski zaangażowany został przez uniwersytet stanu Nowy Jork w Stony Brook jako wykładowca literatury niemieckiej i porównawczej Roman Karst). Na łamach poznańskiego „Nurtu” Stefan H. Kaszyński omówienie udostępnionej w polskim przekładzie prozy Piontka rozpoczął od krótkiej diagnozy aktualnego stanu literatury w Republice Federalnej. Zaczynał od stwierdzenia, że „literatura zachodnioniemiecka przeżywa kryzys, kryzys długotrwały i stale się pogłębiający" (KAsZYŃSKi 1967: 52). Charakteryzując autora Goracych kasztanów, poznański germanista pisał:

Piontek to przede wszystkim poeta, poeta niezwykle subtelny, o wyrafinowanej stylistyce i oryginalnym sposobie widzenia prawdy o człowieku swoich czasów. Wrażliwość poety przeniósł Piontek również do swoich opowiadań. Opowiadania Piontka mają bardzo specyficzny charakter: z pozoru są szorstkie i obojętne, za obojętnością tą kryje się jednak suma doświadczeń życiowych autora, wynik jego długoletnich obserwacji i przemyśleń. [...] Gorace kasztany to proza na wskroś współczesna i aktualna. Współczesność jest tu zarówno tworzywem, jak i materiałem autorskich refleksji, jest wreszcie tkanką łączną klimatów uczuciowych pokolenia „zagubionej generacji”.

KASZYŃSKI 1967: 53

\section{Według Kaszyńskiego}

pisarstwo jest dla Piontka wyzwoleniem z samotności, szukaniem więzi społecznej, akcentowaniem swej obecności w życiu narodu. Bohaterowie opowiadań (właściwie jest to stale ta sama postać) to ludzie odstający w jakiś sposób od ram rzeczywistości. Znając doświadczenia życiowe autora, łatwo zrozumieć powody ich rozchwianej egzystencji. Jednak ludzie ci podejmują zazwyczaj walkę o prawo do normalnego życia, tzn. walkę przeciwko własnej słabości i uległości, walkę przeciw sobie. W tych heroicznych zmaganiach jest jednak coś pięknego, coś głęboko humanistycznego - wiara w człowieka - mimo doświadczeń 
i świadomości nieuchronnej klęski. Ludzie ci podejmują swój ciężki los jako obowiązek. I to właśnie czyni ich odpornymi i lepszymi.

KASZYŃSKI 1967: 53

Szukając dla omawianej prozy literackich odniesien, recenzent stwierdzał: „Wszystkie opowiadania Piontka pisane są bardzo na serio, nie ma w nich zupełnie tak modnej dziś ironii. W tym względzie bliższe one są prozie amerykańskiej czy polskiej niż rodzimej twórczości niemieckiej. Dalekie są również opowiadania Piontka od wszelkich sentymentalizmów" (KASZYŃsKi 1967: 53). Konkluzja omówienia była następująca: „Na zakończenie przyznać trzeba, że lektura Goracych kasztanów nie nastraja zbyt optymistycznie. Jedno jest jednak pewne, proza Piontka ukazuje całą, najgorszą chociażby prawdę o człowieku swoich czasów. Człowieku doby etycznego, kulturalnego i politycznego kryzysu NRF" (KASZYŃsKi 1967: 53).

Dokładniej zajął się tomem Piontka również inny poznański germanista w „Miesięczniku Literackim”. Hubert Orłowski wychodził od refleksji nad stanem moralnego rozliczenia z niedawną historią w najnowszej prozie niemieckiej, w której „brunatna przeszłość rzadko, nader rzadko wdziera się w życie bohaterów, związanych z nią poprzez mniej lub bardziej aktywny w niej udział. Przeszłość była tam, oni są tutaj; oba te światy dzieli najczęściej zapomnienie, obojętność lub akt wewnętrznego odcięcia się, »odwrócenia «" (OrŁowski 1967: 122). Wobec tych typowych ujęć Orłowski sytuował opowiadania Piontka, a właściwie jeden utwór z tomu Gorace kasztany, zatytułowany Zrównanie dnia $z$ noca (Tag- und Nachtgleiche).

Bohater opowiadania, nauczyciel z zawodu, miewa ni to na jawie, ni to we śnie majaki, zwidy; idylliczne sceny mieszają się z symbolami formacji SS. Ucieka z domu [...] do wypranego z osobistych akcentów pokoju hotelowego. Tam zaś, w towarzystwie trzech butelek wina, daje się osaczyć wspomnieniom, przede wszystkim zaś imputowanym tym wspomnieniom życzeniom. Bohater nasz nie może się bowiem pozbyć kompleksu inności; tego, że nie jest w stanie „ustawić się” wobec przeszłości. [...] Rzecz znamienna, że to nie kat, nie człowiek, któremu w sposób jednoznaczny przypisać można zbrodnie, szamocze się z cieniami przeszłości, a jeden z wielu milionów bezwolnych trybików, żołnierz, który w obliczu prawa nie może być uznanym za winnego; co najwyżej mówić można o winie metafizycznej (w rozumieniu Jaspersa). W długiej galerii postaw etycznych najczęściej spotykanych wśród postaci literackich, postawa bohatera opowiadania Piontka jest niezwykle rzadka. I to każe zwrócić uwagę na to opowiadanie, na jego wymowę, na oskarżenie nie wprost. 
Pozostałe utwory najwyraźniej nie znalazły w oczach recenzenta uznania:

Inne opowiadania nie dorównują poprzedniemu. Są wśród nich i takie, których sens ociera się o truizm; to, że starość niesie ze sobą jakże często samotność (Drzewa na wietrze), że brak niekiedy człowiekowi odwagi do uczynienia decydującego kroku (Brama na świat), że dom jest czymśs więcej aniżeli czterema ścianami mieszkania (Dachy), wszystko to nie odbiega znów tak bardzo od tzw. mądrości życiowej. [...] Część pozostałych opowiadań natomiast (Czerwony szlak, Niełatwa sprawa, Złote runo czy Tango wdowca) stoi w bezpośrednim związku z rzeczywistością zachodnioniemiecką; frustracja intelektualisty czy zagubienie się robotników-cudzoziemców staje się tam punktem wyjścia do przeegzaminowania społeczności zachodnioniemieckiej. Jest to problematyka spotykana w prozie Schnurrego, Walsera i innych, wartościowa zapewne, ale nie wybiegająca w swych poznawczych uogólnieniach poza - by użyć terminologii sportowej - klasę krajową.

OrŁOWSKI 1967: 123

Poza tym Orłowski stanowczo polemizował ze zdaniem innego recenzenta, twierdząc, iż „trudno zgodzić się z sądem J. Pluty (»Odra«, 1/67), według którego te opowiadania Piontka posiadają jednoznaczne podteksty (contradictio in adjecto!) w postaci kwestii niemieckiej. Rozpatrywanie tych opowiadań w rygorach poetyki alegorii jest nie do przyjęcia" (OrŁowski 1967: 123). Co interesujące, przywołany polemicznie Jerzy Pluta za "najbardziej interesujacce opowiadanie zbioru” uznał również Zrównanie dnia z nocq (Pluta 1967: 84). Temu właśnie utworowi podobną rangę („ostatnie - i najlepsze - opowiadanie tomu”) przyznawał Zbigniew ŻABICKI (1967: 37). To opowiadanie wyróżniał także Stefan H. Kaszyński - i z niego wyprowadzał jeden z końcowych wniosków: „Właśnie pytanie: kim jestem? - chęć stania się kimś innym - zbliża penetracje literackie Heinza Piontka do koncepcji filozoficznej pisarstwa Maxa Frischa” (KASZYŃski 1967: 53). Zwracał jednak uwagę również na inne utwory. Utrzymywał, że „w konwencji Frischa utrzymany jest też najbardziej osobisty odcinek prozy tego tomu pt. Niełatwa sprawa” (KASZYŃSKI 1967: 53). Pluta wskazywał także na inne „kapitalne opowiadanie $\mathrm{Na}$ wsi”, opatrując je charakterystycznym dopiskiem: „polecam je gorąco rodzimym smakoszom »autentyków « w rodzaju Brychta" (Pluta 1967: 84).

Niekiedy oceny tego samego utworu bywały rozbieżne, co może wskazywać na trudności z odczytaniem udostępnionej nowelistyki Piontka. Co dla Orłowskiego „ociera się o truizm”, dla Kaszyńskiego ma niewątpliwą wartość, kiedy pisze: „W jednym chyba tylko wypadku 
ponosi autora nostalgia, myślę tu o opowiadaniu Drzewa na wietrze jednak doskonałe opanowanie warsztatu i wielka kultura literacka dozwala pisarzowi uniknąc spłycenia i zwulgaryzowania tego problemu" (KASZYŃSKI 1967: 53).

Natomiast niewymieniany raczej w innych recenzjach utwór Nic tu po tobie, obcy człowieku, choć pojawił się bez podania tytułu, zaciekawił najbardziej Włodzimierza Maciąga: „Jedno zwłaszcza opowiadanie zrobiło na mnie wrażenie, opowiadanie, w którym młody człowiek przyjeżdża do młodziutkiej dziewczyny - i wbrew sobie, wbrew zamiarom i postanowieniom wiąże się jakąś nieopanowaną namiętnością z matką dziewczyny" (MaciąG 1967).

Zbiorczego omówienia przekładów z literatury niemieckiej, opublikowanych w 1966 roku, dokonał Roman Karst w „Roczniku Literackim". Nie ma ono jednak charakteru podsumowania; jest raczej jeszcze jednym odczytaniem udostępnionego polskiemu czytelnikowi tomu nowel, dokonanym przez doświadczonego recenzenta i komentatora literatury niemieckojęzycznej. Zdaniem Karsta „są to miniaturowe szkice lub migawkowe zdjęcia, które jak gdyby zatrzymują w biegu jakąś przelotną albo godną zapamiętania chwilę, rysują zawiłą sytuację, osobliwą postać, krajobraz, odruch uczucia. Na ludzi i wydarzenia pada tu na krótko nieoczekiwany snop światła, potem wszystko znika z oczu, ginie w ciemności. Kompozycja nowel jest »otwarta«, pisarz nie stawia kropki nad »i«, nie daje jednoznacznych rozwiązań, pozostawiając ich poszukiwanie czytelnikowi. Niektóre nowele autor powleka patyną poetyczności, co zresztą nie wychodzi im na dobre" (KARst 1966: 556). Autor przeglądu wyróżnia w tomie, jego zdaniem „zawierającym dwanaście opowiadań psychologicznych”, przeważnie inne tytuły niż wcześniejsi recenzenci.

Do ciekawszych utworów tego wyboru należą: Złote runo, opowiadanie z życia włoskich robotników pracujących w Niemczech Zachodnich, Niełatwa sprawa, historia pisarza, który się przeobraża w zawodowego niemal uczestnika przeróżnych konferencji literackich, wreszcie Niedźwiedzi smutek, ironiczna nowela o młodym, zakochanym chłopcu.

KARST 1966: 556

Większość recenzentów starała się odnaleźć w opowiadaniach Piontka elementy uwikłania w najnowszą historię: kwestię pochodzenia autora, ślady niedawnej przeszłości oraz sposoby jej przezwyciężania. (Chociaż niektórzy, jak Sadkowski i Maciąg, akurat te sprawy pomijali). Szeroko do (nie)obecności problemu winy i moralnej odpowiedzialności w niemieckiej literaturze odnosił się - o czym była już mowa - Orłow- 
ski. Analizował Zrównanie dnia z noca, każąc „Zwrócić uwagę na to opowiadanie, na jego wymowę, na oskarżenie nie wprost". Zdaniem poznańskiego historyka literatury niemieckiej

tylko jeden pisarz, a mianowicie Martin Walser, posunął się dalej w tej demaskacji letargu sumienia katów. W jego sztuce Czarny łabędź nie zbrodniarz, lecz jego syn przejmuje na siebie przeszłość oraz winy ojca (aż do częściowego zatarcia granic tożsamości). U Piontka to zatracenie tożsamości własnego ,ja” nie rzuca się co prawda w oczy, tym niemniej istnieje. $Z$ tym, że sens postawy bohatera opowiadania jest ambiwalentny; $\mathrm{z}$ jednej strony jest to afirmacja wrażliwości sumienia, ciągłości w rozwoju indywidualnym, z drugiej natomiast sygnał wskazujący na ciążenie spetryfikowanych sposobów traktowania własnej przeszłości.

ORŁOWSKI 1967: 123

Kwestię podjętą przez Orłowskiego rozwijał Zbigniew Pędziński, choć do problemu podchodził zupełnie inaczej. Zacytujmy jego wywód:

Piontek, kreśląc obrazki z życia Niemców współczesnych, umieszcza je w światłocieniu przeszłości, tej wojennej, tej hitlerowskiej, tej, o której wielu jego rodaków zapomnieć nie może, choć zapomnieć pragnie. Przeszłość nie jest $\mathrm{w}$ tych opowiadaniach formalnie paralelnym, równoległym ideowo, a nawet równouprawnionym artystycznie wątkiem: wystarczy dla orientacji wczytać się w opowiadanie tytułowe ${ }^{14}$ [właśc. Czerwony szlak - K.P.], gdzie dosłownie kilka motywów, może zgoła parę zdań, nawiązuje do owej historycznej ekspozycji okrutnej w przebiegu i epilogu wyprawy kilku młodych ludzi w góry. Ale ich bezmyślność, tępy a okrutny sadyzm, który pozostaje na długo w pamięci czytelnikowi po odwróceniu ostatniej kartki, ma jakieś głębokie powinowactwa i analogie z życiem, postawą ojców tych młodych ludzi, prowokuje do analogicznej oceny, refleksji, kontrowersji. Właśnie kontrowersji, ponieważ - owo starsze pokolenie potrafiło się niekiedy bodaj na moment otrząsnać z tego samego permanentnie ogłupiającego konformizmu, który pozostaje dotąd najbardziej własnym, niemal strzeżonym pieczołowicie stylem życia ich synów i wnuków.

Ktoś, kto sięgnie do następnych opowiadań Goracych kasztanów, może po ich lekturze gorąco zaprotestować przeciw memu ostatniemu sformułowaniu: przecież właśnie $\mathrm{w}$ tych utworach święci tryumfy oczywisty antykonformizm, zdzierający maski i koturny bohaterom

${ }_{14}$ Mowa tutaj o otwierającym tom opowiadaniu, jednak nie o utworze tytułowym, ponieważ w tomie brak takiego (tytuł Gorace kasztany nie ma odpowiednika w tytule żadnego z opowiadań pomieszczonych w tomie). 
różnych, przede wszystkim jednak młodych formacji pokoleniowych. Tak, ale jest to jednak antykonformizm pozorny, a raczej - pozorów, za których fałszywą monetę sprzedaje się lekko, a w każdym razie z wielkopańskim gestem, autentyczną, rzetelną miłość, przyjaźń czy, ogólniej, wiarę w sens życia, w jego moralne i społeczne uzasadnienie.

PĘDZIŃSKI 1967

Sprawę rodowodu niemieckiego pisarza podejmował Jerzy Pluta, który w swojej recenzji podkreślał: „Interesuje nas przecież bardzo, jak sprawy śląskie, tak skomplikowane i ciągle jeszcze należycie nieoświetlone, traktuje pisarz zachodnioniemiecki ze Śląska (Piontek urodził się w roku 1925 w Kluczborku)" (Pluta 1967: 84). Odwołując się do ustaleń Wilhelma Szewczyka w związku z prezentacją twórczości Piontka (w Literaturze niemieckiej $w X X$ wieku), ten sam recenzent pisał:

Najcenniejsze bowiem w odkryciu Szewczyka było uświadomienie naszej opinii społecznej, że w NRF tworzą także pisarze, tzn. pisarze nietuzinkowi, którzy mimo urodzenia na Śląsku potrafili wyjść daleko poza rewizjonistyczne rogatki, którzy po prostu realistycznie oceniają współczesną rzeczywistość niemiecką. I w swym szkicu Szewczyk wypunktował przede wszystkim tematykę śląską Piontka.

Pluta 1967: 84

Natomiast Kaszyński w charakterystyce autora Goracych kasztanów zaznaczał:

Profil intelektualny tego pisarza znaczony jest kompleksami pokolenia, które przeżyło koniec pewnej epoki historycznej, u Piontka dochodzi do tego jeszcze kompleks przesiedleńca. Heinz Piontek pochodzi, jak wiadomo, z Kluczborka. Na zachodzie osiedlił się dopiero po powrocie z niewoli amerykańskiej. Kompleksy te nie są jednak tematem pisarstwa Heinza Piontka, tkwią one raczej głęboko w podświadomości pisarza, jako coś bardzo bolesnego i osobistego. Dlatego też nie udało się działaczom przesiedleńczym pozyskać dla swej propagandy pióra wytrawnego pisarza.

KASZYŃSKI 1967: 52-53

Kwestia ta zajęła także recenzenta „Liter”:

Wróćmy jeszcze na chwilę do miejsca urodzenia Piontka i jego stosunkowo młodego wieku: te dwa fakty determinowały niejako autora Goracych kasztanów na artystycznego co najmniej piewcę idei ziomkowskich i przesiedleńczych, które (tudzież ukrywające się za nimi bodźce społecznego i ekonomicznego profitu) uwiodły niejednego, równie dobrze, jeśli nie bardziej obiecująco zapowiadającego się pisa- 
rza. Dlaczego Piontek nie stał się jednym z tych uwiedzionych - pośrednią, ale tym więcej przekonującą odpowiedź znajdziemy zarówno w Goracych kasztanach, jak w wywiadzie ze sobą samym, który autor tych opowiadań przeprowadził na łamach „Die Welt der Literatur”. To tytuł tego wywiadu posłużył właśnie za nagłówek niniejszej recenzji.

PĘDZIŃSKI $1967^{15}$

Odwołanie się do autokomentarza Piontka wyróżniało omówienie Pędzińskiego, które właściwie zamykało bieżący odbiór Gorących kasztanów w Polsce.

Można zauważyć, że polski „protektor” Heinza Piontka - Wilhelm Szewczyk, w swojej publicystyce powracał jeszcze przez pewien czas do jego postaci, działalności i postawy. Okazja taka nadarzyła się w felietonie poświęconym zasługom Karla Dedeciusa w przyswajaniu polskiej literatury na terenie Niemiec Zachodnich.

Szczególnie wnikliwe uwagi wywołała jego [K. Dedeciusa - K.P.] antologia poezji polskiej XX wieku, wydana w roku $1964 \mathrm{w}$ ambitnym wydawnictwie Carla Hansera. Znany także i u nas - raczej jako prozaik w związku z przekładem jego opowiadań Gorace kasztany - poeta Heinz Piontek stwierdził po jej ukazaniu się na łamach „Süddeutsche Zeitung”, że zapoczątkowała ona „współbrzmienie dwóch literatur”. Pod jego piórem stwierdzenie to nabiera dodatkowej wymowy, gdyż Piontek jest pisarzem pochodzącym ze Śląska [...] i na skutek tego stale uparcie kokietowanym przez tzw. Ziomkostwo Ślązaków, zresztą czasem nie bez skutku, gdy na łamach „Schlesiera” pozwala przedrukowywać niektóre swoje liryki.

WISZ 1967

W tym kontekście Piontek pojawił się (obok Horsta Bienka) jako istotny punkt odniesienia w referacie Szewczyka Wspótczesna niemiecka literatura rewizjonistyczna o naszych ziemiach zachodnich i pótnocnych, wygłoszonym na IX Zjeździe Pisarzy Ziem Zachodnich i Północnych w Bydgoszczy (26-28.05.1966), wydrukowanym niebawem (w czerwcu 1966 roku) na łamach „Życia Literackiego” pt. Przez okulary z firmy Brauxel et $\mathrm{Co}^{16}$, który jako Okulary z firmy Brauxel \& Co wszedł później do krytycznoliterackiego tomu pod tym samym tytułem. Śląski aktywista zajął się w nim ,pewną grupą beletrystów i poetów związanych

15 Autor recenzji nie podawał bliższych danych owego autowywiadu, które wypada tutaj uzupełnić: PIONTEK 1966b.

16 (SzEwczyk 1966) (o H. Piontku na s. 4). Należy zauważyć, że Szewczyk opracował ten temat nieco wcześniej w artykule zamieszczonym w ukazującym się języku angielskim półroczniku „Polish Western Affairs” - zob. SzEwCzYK 1963 (o H. Piontku na s. 137,143$)$. 
z ruchami ziomkowskimi i starających się realizować ich odwetowe programy polityczne w własnej twórczości literackiej” (SzEwczyK 1969: 89). Autor czynił tam następującą obserwację, związaną także z artystycznymi (i poniekąd politycznymi) wyborami pisarza z Kluczborka:

Szeroki krąg twórców odwetowych różnicuje się coraz bardziej. Wielu z tych, którzy rozpoczynali pierwsze kroki na łamach organów ziomkowskich, zdobywszy tymczasem rozgłos i większe doświadczenie intelektualne, odeszło od tematyki odwetu. Poruszają się w świecie innych wyobrażeń literackich, a nawet politycznych. I jeśli nawet jeszcze widuje się na przykład takiego Heinza Piontka, rodem z Kluczborka, na uroczystościach ziomkowskich, twórczość jego znalazła sobie inne orbity, jak gdyby nie miał wcale zamiaru rezygnować ze spokoju na skałach, którymi to słowami zakończył swój znany wiersz Rozprosze$n i$, mający za temat ucieczkę Niemców ze Śląska.

SZEWCZYK 1969: 109-110

Jako analogiczny przykład Szewczyk wskazywał na Bienka, „uzdolnionego poetę i eseistę, gliwiczanina”, którego poemat Gliwickie dzieciństwo (Gleiwitzer Kindheit) podawał w tym samym tekście we własnym tłumaczeniu. Wywód zmierzał do konkluzji:

Na nic więc nie zdadzą się wysiłki wielu niepoprawnych, aby w pieśni pełnej otuchy i odwetu zamknąć czas klęski i ucieczki z Nadodrza. Po raz drugi już zabrzmi w poezji zachodnioniemieckiej ów szlachetny ton zapomnienia i oskarżenia, ujęty w słowa doskonałe: najpierw Heinz Piontek w Rozproszonych, teraz zaś mocniej jeszcze Horst Bienek w Gliwickim dzieciństwie, mocniej i dokładniej, bo po raz pierwszy utwór o tematyce ucieczki wylicza, ukryte $\mathrm{w}$ poetyckich obrazach, przyczyny klęski, zbrodnie, które ją poprzedziły.

SZEWCZYK 1969: 116

Dla dopełnienia obrazu trzeba zaznaczyć jeszcze jedną krytycznoliteracką pozycję książkową z 1968 roku - Wacława Sadkowskiego Drogi $i$ rozdroża literatury Zachodu, do której autor (w rozdziale Drogi $i$ rozdroża literatury niemieckiej) przeniósł, właściwie bez zmian, swoje recenzenckie uwagi dotyczące Goracych kasztanów, poczynione dwa lata wcześniej w „Trybunie Ludu”. Dopowiadał jedynie, że „najcenniejsze zresztą w dorobku pisarskim Piontka są właśnie opowiadania, w których "zmysł pointy« i finezja kompozycyjna pisarza wypowiedziały się najswobodniej" (SADKowski 1968: 153). Warto jednak zauważyć, że swoje obserwacje Sadkowski rozszerzył o - poznaną w oryginale - pierwszą powieść niemieckiego poety i nowelisty: 
Nad opublikowaną w roku 1966 powieścią Piontka Die mittleren Jahre, mimo jej epickich ambicji (a może właśnie wskutek tych nazbyt rozległych zamierzeń), wydaje się ciążyć pewna nieumiejętność budowania rozwiniętej, wielofazowej fabuły - Piontek jest raczej mistrzem szkicu, aluzji, „niedookreślenia” - ale i w niej znaleźć można sporo przenikliwych uwag o sposobie odczuwania i reagowania uczuciowego, charakterystycznym dla inteligenckich kręgów zachodnioniemieckich, pisarz stara się tu jakby prześledzić proces kształtowania się i formowania owej szczególnej postawy swoistego sceptycyzmu pragmatycznego.

W latach 60., zwłaszcza pod koniec dekady, a następnie w kolejnym dziesięcioleciu, wyraźniej zaznaczył się udział środowiska germanistycznego w prezentacji współczesnej literatury RFN. Wśród przyswajanych autorów nie zabrakło również Heinza Piontka. Początkowo były to jedynie drobne wzmianki, jak miało to miejsce wcześniej w referacie Mariana Szyrockiego Literatura Niemiec Zachodnich. Kierunki i problemy, wygłoszonym 3.04.1962 roku w Śląskim Instytucie Naukowym, który w roku następnym - w wersji poszerzonej i uzupełnionej - ukazał się jako samodzielna publikacja katowickiej placówki (SZYROскI 1963b) ${ }^{17}$. Piontek (obok I. Bachmann, P. Celana, H.M. Enzensbergera, W. Höllerera i G. Grassa) został wymieniony wśród „młodszej generacji zdolnych liryków”, którzy wkroczyli w życie literackie w latach $50 .{ }^{18}$. Chyba bez ryzyka poważniejszej pomyłki można stwierdzić, że referat i wydana na jego podstawie broszura były produktem ubocznym pracy wrocławskiego germanisty nad pierwszą wersją Historii literatury niemieckiej (1963), w której jednak nazwisko Piontka się nie pojawiło ${ }^{19}$.

Dokonujący się w dydaktyce uniwersyteckiej zwrot ku literackiej współczesności miał oczywiście swoje zewnętrzne uwarunkowania. Dostrzegalny wzrost zainteresowania literaturą zachodnioniemiecką i (względne) jego zaspokajanie poprzez zwiększoną podaż przekładów na język polski miał miejsce na przełomie lat 50 . i 60 ., by w ciągu jednego tylko roku 1962 osiągnąć liczbę już 10 tłumaczonych pozycji książkowych (dla porównania: w całym okresie poprzedzającym te zmiany, w latach 1949-1956, przełożono ogółem zaledwie 4 pozycje z literatury RFN!) ${ }^{20}$.

17 Informacja o pierwotnym przeznaczeniu tekstu - SzYrocki 1963b: 5, przyp. *.

18 Zob. SZYrocki 1963b: 21. W tym fragmencie autor powołuje się w przypisie na pracę Waltera JENSA (1961: 56-57).

${ }_{19}$ Historia literatury niemieckiej. Zarys M. Szyrockiego miała dwa, różniące się od siebie, wydania $(1963,1971)$. W żadnym z nich H. Piontek nie został uwzględniony.

20 Por. zestawienia dokonane w pracy K.A. Kuczý́skiego (1981). 
Uprawiana na polskich germanistykach historia literatury nie pozostawała obojętna na te symptomy przemian. Drugi czynnik wynikał z wprowadzania w drugiej połowie lat 60. przez Ministerstwo Szkolnictwa Wyższego nowych, ujednoliconych programów studiów germanistycznych. Wydane w 1966 roku przez Departament Studiów Uniwersyteckich i Ekonomicznych rzeczonego Ministerstwa Programy ramowe $i$ plany studiów dla filologii germańskiej ustalały „pewną hierarchię przedmiotów w procesie nauczania” i określały „zakres wiadomości” (Programy 1966: 5) do przyswojenia przez studentów. I tak, „magister filologii germańskiej winien się wykazywać [...] ze względu na racje polityczne, kulturalne itp.” - ,a) dobrą znajomością literatury współczesnej oraz okresów rozkwitu literatury niemieckiej [...], b) dobrą znajomością historii kultury, historii współczesnej niemieckiego obszaru językowego" (Programy 1966: 5). W podsumowaniu uwag wstępnych można przeczytać w punkcie 1: „Wyżej wymieniona hierarchia celów procesu nauczania w zakresie wiadomości, jakie winien posiadać magister filologii germańskiej, wskazuje na to, że w samym procesie nauczania należy szczególnie silnie rozbudować zagadnienia współczesne” (Programy 1966: 5). W kolejnej broszurze, wydanej w pierwszej połowie lat 70. przez Ministerstwo Nauki, Szkolnictwa Wyższego i Techniki, znajdują się już uszczegółowione wytyczne dotyczące uniwersyteckich programów i planów studiów germanistycznych; w rozdziale VII części B wśród zasługujących na omówienie zjawisk w literaturze RFN wskazana została poezja hermetyczna, konkretna i zaangażowana - w szeregu reprezentatywnych nazwisk (Benn, Eich, Krolow, Rümkorf, Enzensberger, Grass, Meister, Sachs, Kaschnitz, Domin, Borchers) pojawił się również Piontek (Uniwersytety 1974: 21).

Tłem tych zmian, otwierających polskiemu odbiorcy szerszy niż dotychczas dostęp do kultury i literatury Niemiec Zachodnich, było wydarzenie polityczne (w sferze relacji międzynarodowych) - podpisanie po długich negocjacjach w Warszawie 7.12.1970 roku przez rządy RFN i PRL układu o podstawach normalizacji wzajemnych stosunków (ratyfikowany przez stronę niemiecką dopiero 17.05.1972, a następnie - po sejmowych opiniach i debatach - przez Radę Państwa PRL 28.05.1972) ${ }^{21}$.

${ }^{21}$ Zawarcie tego porozumienia na płaszczyźnie dyplomatycznej miało swoje widoczne konsekwencje, wyrażające się w różnych formach. Jak odnotował historyk: „Pierwsza połowa lat siedemdziesiątych była dla Polski czasem intensywnych dążeń do normalizacji stosunków z RFN. Uzgodnienia polskich i niemieckich polityków umożliwiły nawiązanie ożywionych kontaktów elit politycznych, którym początek dała wizyta w Polsce w lutym 1971 r. Herberta Wehnera, przewodniczącego frakcji parlamentarnej SPD w Bundestagu. W efekcie zadzierzgniętych więzów między przywódcami PZPR i SPD zapoczątkowano obyczaj wzajemnych wizyt grup parlamentarnych obu partii [...]. 
$\mathrm{Na}$ ten czas przypada wdrożenie reformy szkolnictwa wyższego w PRL, w wyniku której doszło do likwidacji dotychczasowych katedr germanistycznych i przekształcenia ich w instytuty. Ta sytuacja miała miejsce w czołowych ośrodkach tego okresu: w Poznaniu, gdzie na Uniwersytecie im. Adama Mickiewicza od 1969 roku zaczął działalność Instytut Filologii Germańskiej, w ramach którego powołany został między innymi Zakład Historii Literatury Niemieckiej, oraz we Wrocławiu - na Uniwersytecie Wrocławskim im. Bolesława Bieruta po przekształceniu w 1969 roku Katedry w Instytut Filologii Germańskiej utworzono w jego strukturze Zakład Literatury i Kultury Współczesnej Niemiec, Austrii i Szwajcarii. Odtąd w programach studiów pojawiła się jako stały element literatura RFN. Właśnie badacze z wymienionych ośrodków (a z czasem także $\mathrm{z}$ innych uniwersytetów) - nierzadko $\mathrm{w}$ powiązaniu z podejmowaną na wyższej uczelni pracą badawczą i dydaktyczną aktywniej włączyli się $\mathrm{w}$ przyswajanie polskiej publiczności literatury zachodnioniemieckiej.

Ze względu na obecność Heinza Piontka w Polsce pod koniec lat 60. odnotować wypada dwie osobne publikacje o charakterze skryptów uniwersyteckich, napisane $\mathrm{w}$ języku niemieckim i przeznaczone dla studentów germanistyki ${ }^{22}$. Obie pozycje ukazały się nakładem Państwowego Wydawnictwa Naukowego w 1968 roku, osiągając po dwa wydania. Przygotowana w ośrodku poznańskim przez Ludmiłę Sługocką antologia nosiła tytuł Über die Grenzen hinaus. Deutsche Polenlyrik seit den Anfängen bis 1965 (Auswahl). W tym przekrojowym wyborze poetyckich utworów na temat Polski uwzględniony został jeden krótki wiersz Piontka Zurückgenommenes Dasein, zamieszczony w części IX, obejmującej okres po II wojnie światowej (In der Nachkriegszeit), w rozdziale 6,

Tak prowadzona polityka obu partii umożliwiła organizowanie cyklicznych spotkań »okrągłego stołu«, w których brali udział parlamentarzyści, naukowcy i publicyści PRL i RFN. [...] Pokłosiem tych spotkań przy okrągłym stole była tzw. idea Forum Polska RFN, jedyna w owym okresie taka forma współpracy w stosunkach między państwami socjalistycznymi a krajami Europy Zachodniej. Podczas wizyt, organizowanych naprzemiennie w Polsce i w RFN co dwa, trzy lata, omawiano aktualne problemy relacji między obydwoma krajami, a ich uczestnicy mieli duży wpływ na kształtowanie opinii publicznej w swoich krajach" (FIC 2007: 180-181).

22 Poszczególne opracowania, poświęcone niemieckojęzycznej liryce, dramatowi i prozie, ogłaszane drukiem w latach 1968-1969, pomyślane były jako pomoc dla studentów germanistyki w Polsce i składały się na podręcznikowy zarys literatury niemieckiej. Odnośne plany oraz postanowienia podjęto na konferencji przedstawicieli polskiej germanistyki uniwersyteckiej w Ustroniu 22-23.03.1966 roku, o czym informował M. Szyrocki w liście z 25.04.1966 r. do redakcji Państwowego Instytutu Wydawniczego (zob.: Biblioteka Instytutu Filologii Germańskiej UWr, Spuścizna M. Szyrockiego, sygn. M 212; por. POLECHOŃSKI/KUNICKI 2015: 131-133). 
dotyczącym problemu przesiedleńców (Zum Umsiedlerproblem), w którym autor reprezentował stronę zachodnioniemiecką (SŁUGocka 1968: 152). Drugi skrypt, Deutsche Lyrik des 20. Jahrhunderts, to praca wrocławskich germanistów, Anny Stroki i Mariana Szyrockiego. W części autorstwa Szyrockiego (Deutsche Lyrik vom Ausgang des ersten Weltkrieges bis zur Gegenwart) pojawił się Piontek, a w lapidarnej charakterystyce wymienione zostały dwa najwcześniejsze jego tomy (z lat 50.) oraz hasłowo rysy jego postawy poetyckiej; jako przykład nastrojowego obrazka rodzajowego przytoczony został utwór Das Mahl der Straßenwärter (STROKa/SZYRocki 1968: 72).

Jeszcze jeden przejaw obecności autora Goracych kasztanów w Polsce wart jest odnotowania, tym razem jako komentatora i interpretatora twórczości innych poetów, zwłaszcza polskich. W 1970 roku, w czerwcowym numerze „Twórczości”, w przeglądzie austriackich czasopism kulturalnych, poświęcono uwagę szkicowi Piontka o poezji Herberta, zamieszczonemu w „Wort und Wahrheit” (marzec-kwiecień 1970, nr 2). Przytoczmy ten fragment w całości:

Dla nas szczególnie jest interesujący artykuł Heinza Piontka o liryce Zbigniewa Herberta (pt. Jedyny dogmat: człowieczeństwo), poprzedzony i ilustrowany przekładami pióra Dedeciusa. [...] Po krótkim szkicu biograficznym, niezbędnym dla czytelnika austriackiego, Piontek analizuje poetykę Herberta. Autonomizowaniu i absolutyzowaniu języka, które coraz bardziej staje się modą w liryce zachodnioniemieckiej i austriackiej, przeciwstawia swoisty dla liryki Herberta antropologizm i humanizm. Analizuje jego metaforykę, ukazując, że nie ma w niej dowolności ani samej tylko igraszki, jego parabole, w których fantazja zakotwiczona jest $\mathrm{w}$ doświadczeniu i które dlatego odbierane są przez czytelników bezbłędnie. Rangę poetycką Herberta ocenia Piontek bardzo wysoko, pisząc, że wśród jego utworów niewiele jest takich, które nie ostaną się przemijaniu

$$
\text { b (= KROŃSKa Irena) 1970: 137-138 } 23
$$

Przy okazji można wspomnieć, że z polskich poetów oprócz Herberta zainteresowaniem i uznaniem darzył Piontek Tadeusza Różewicza, którego niemieckie wydania wierszy recenzował ${ }^{24}$. W księgozbiorze pol-

${ }^{23}$ b (1970: 137-138). Por. Piontek 1970a. O poezji Herberta pisał Piontek kilkakrotnie: (PionteK 1969a); (PIONTEK 1974a); (PionteK 1974b) [rec.: Zbigniew Herbert: Herr Cogito. Gedichte. Übertr. Karl Dedecius. Frankfurt am Main: Suhrkamp, 1974].

24 (Piontek 1966c) [rec.: Tadeusz Różewicz: Formen der Unruhe. Gedichte. Übertr. Karl Dedecius. München: Hanser, 1965]; (PionteK 1969b); (Piontek 1969c); (PionteK 1970b) [rec.: T. Różewicz: Offene Gedichte (1945-1969). Übersetzt von K. Dedecius. München: Hanser, 1969]. 
skiego poety, przekazanym obecnie Bibliotece Ossolineum we Wrocławiu, znajduje się egzemplarz wydanego w 1966 roku tomu poetyckiego Klartext z odręczną dedykacją autora: „Für Tadeusz Różewicz, den Dichter der »Formen der Unruhe«, herzlich / Heinz Piontek / München / 1.9.1966" "25. Obu poetom, Herbertowi i Różewiczowi, poświęcił Piontek szkice w krytycznoliterackim tomie Männer die Gedichte machen. Zur Lyrik heute (Hamburg 1970). Natomiast twórcę Niepokoju jako jedynego z polskich autorów uwzględnił Piontek w ułożonej przez siebie antologii wypowiedzi pisarzy o właściwościach, blaskach i nędzach literackiego fachu pt. Jeder Satz ein Menschengesicht. Schriftsteller berichten über ihren Beruf (PiONTEK 1969c: 78).

W latach 70. ważną rolę pośredniczącą odegrały dwie antologie: prozy oraz poezji RFN. W tym kontekście trzeba zaznaczyć, że wydawnictwa przekrojowo ukazujące literaturę zachodnioniemiecką były nieliczne i pojawiły się późno, niemal trzydzieści lat po zakończeniu II wojny światowej (i ćwierć wieku po proklamowaniu Republiki Federalnej) ${ }^{26}$. Jako pierwszy w 1974 roku ukazał się nakładem Państwowego Instytutu Wydawniczego w Warszawie Nieznany cel. Antologia opowiadań RFN, w wyborze i ze wstępem Huberta Orłowskiego ${ }^{27}$. Była to - co podkreślał jeden z recenzentów, Marian Szyrocki - „W ogóle pierwsza antologia literatury RFN w Polsce" (SzYrocki 1975: 11). Antologia Orłowskiego oczywiście zwróciła powszechną uwagę, a na łamach prasy literackiej doczekała się w znacznej mierze omówień fachowców, znawców literatury niemieckiej i - przynajmniej po części - uniwersyteckich germanistów, których głos mógł być uznawany za

${ }^{25}$ Heinz Piontek: Klartext. Hamburg: Hoffmann \& Campe 1966, egz. Biblioteki Zakładu Narodowego im. Ossolińskich, sygn. 1.008.388. Formen der Unruhe nosił tytuł pierwszy wybór wierszy Różewicza, który ukazał się po niemiecku w przekładzie Karla Dedeciusa.

${ }^{26}$ Okoliczności tego stanu rzeczy zaznaczał w swojej recenzji pierwszej polskiej antologii tej literatury wrocławski germanista Marian Szyrocki: „Droga do normalizacji naszych stosunków z Republiką Federalną Niemiec była długa i uciążliwa, co znalazło również swój wyraz w recepcji literatury tego kraju u nas" (SzYrocki 1975: 11).

27 Liczący ponad 450 stron tom obejmował 62 utwory 47 autorów. Byli to (w kolejności alfabetycznej): Alfred Andersch, Stefan Andres, Jürgen Becker, Hans Bender, Heinrich Böll, Wolfgang Borchert, Uwe Brandner, Hans Daiber, Peter Faecke, Christian Ferber, Günter Bruno Fuchs, Günter Grass, Max von der Grün, Helmut Heissenbüttel, Wolfgang Hildesheimer, Heinz Huber, Uwe Johnson, Hermann Kasack, Marie Luise Kaschnitz, Hermann Kesten, Alexander Kluge, Wolfgang Körner, Ernst Kreuder, Elisabeth Langgässer, Hermann Lenz, Siegfried Lenz, Reinhard Lettau, Angelika Mechtel, Hans Erich Nossack, Heinz Piontek, Hans Werner Richter, Luise Rinser, Erika Runge, Paul Schallück, Heinrich Schirmbeck, Arno Schmidt, Ernst Schnabel, Wolfdietrich Schnurre, Thomas Valentin, Günter Wallraff, Martin Walser, Peter Weiss, Theodor Weissenborn, Günter Westerhoff, Wolfgang Weyrauch, Gabriele Wohmann, Wolf Wondratschek. 
miarodajny. Mimo nieuniknionych zastrzeżeń oceny były przeważnie przychylne ${ }^{28}$.

Omówienia Nieznanego celu starały się wydobyć zasadę selekcji utworów i ich układu w tomie. Maria Krysztofiak uznała, że „założeniem autora wyboru, Huberta Orłowskiego, było, jak wynika to ze wstępu, przedstawienie zarówno najbardziej reprezentatywnych utworów i twórców, jak i najbardziej różnorodnych, niekoniecznie najlepszych nowel z lat 1945-1971” (Krysztofiak 1975). Natomiast Włodzimierz Bialik pisał:

Antologia Orłowskiego zawiera 63 utwory 46 autorów ${ }^{29}$ uszeregowanych według porządku chronologiczno-tematycznego, czyli według chronologii pojawiania się lub przewagi określonych problemów, tematów czy konwencji [...]. Orłowski ugrupował opowiadania RFN w układ znaczący, naszkicował poprzez nie drogę rozwoju literatury zachodnioniemieckiej. [...] mają te krótkie teksty pewien wspólny rdzeń, ich graficznym obrazem musiałyby być linie, z których żadna nie przecina granicy dla nich nieosiągalnej, a nawet się do niej nie zbliża. Granica ta to opis stanu rzeczy.

BIALIK 1975

Tak też niemieccy pisarze różnych generacji i orientacji - zdaniem recenzenta - „stawiają diagnozę, lecz poza nią nie wychodzą. Niekiedy przenikają w pobliże przyczyn, lecz nigdy nie sugerują terapii” (BıALIK 1975).

Tom zawierał jeden utwór Piontka pt. Brat i brat (Bruder und Bruder) $)^{30}$, przełożony przez Leonię Martynę Gradstein. Opowiadanie niebanalnie ukazywało powojenną rzeczywistość Zachodnich Niemiec; odkrywało - za pomocą mikroobserwacji krótkiego spotkania na dworcu kolejowym dwóch braci - inną stronę „cudu gospodarczego”, odsłaniając pogmatwane, rozmaicie układające się wskutek wojny i jej następstw

${ }^{28}$ Co więcej, oprócz bieżących recenzji antologia Orłowskiego - obok dwu innych wydawnictw o podobnym charakterze, dotyczących nowelistyki twórców austriackich (LICHAŃSKI red. 1973) oraz pisarzy z NRD (50 opowiadań 1974; z przedmową Wilhelma Szewczyka) - była przedmiotem dyskusji, zorganizowanej przez redakcję miesięcznika „Literatura na Świecie” parę miesięcy po ukazaniu się Nieznanego celu. Wzięli w niej udział germaniści, tłumacze, krytycy literatury niemieckiej oraz antologiści: Barbara Surowska, Jacek S. Buras, Jan Koprowski, Stefan Lichański, Hubert Orłowski i Karol Sauerland (zob.: Wokót antologii 1975). Rozmowa oscylowała wokół kilku zasadniczych kwestii, m.in. wyboru tekstów, sposobu opracowywania antologii oraz właściwego dla edycji doboru komentarza. Porównanie wydanych trzech antologii niemieckojęzycznej prozy pozwalało ocenić dokonane w każdym przypadku decyzje redaktorów.

29 Najprawdopodobniej recenzent pomylił się w obliczeniach.

30 Opowiadanie pochodzi z tomu Vor Augen (1955). 
niemieckie, a jednocześnie ludzkie losy; dyskretnie sygnalizowało również problem utraty ziem rodzinnych i wykorzenienia... Utwór ten, jako dość charakterystyczny, wskazywała recenzentka Nieznanego celu, Maria Krysztofiak, pisząc o problematyce podejmowanej przez niemieckich autorów urodzonych w latach 1910-1930: „W ich utworach pojawia się często temat wojny, nie zawsze wprawdzie w formie odzwierciedlania ówczesnych wydarzeń, lecz nierzadko są to reminiscencje kontrastujące z teraźniejszością, wymagające konfrontacji postaw, jak w opowiadaniu Brat $i$ brat Piontka czy Stare należności Siegfrieda Lenza” (Krysztofiak 1975).

Ze względu na nikłą obecność śląskiego autora należy odnotować, że to samo opowiadanie w tym samym tłumaczeniu zaskakująco - bo już po wydrukowaniu antologii - pojawiło się jeszcze w innym miejscu: na łamach „Zwierciadła”, popularnego magazynu ilustrowanego adresowanego do kobiet, podejmującego problematykę społeczno-obyczajową. Opatrzono je krótką informacją, że tekst przeznaczony jest do antologii opowiadań zachodnioniemieckich (PiONTEK 1975).

Drugim poważnym przedsięwzięciem, przedstawiającym dokonania zachodnioniemieckiej literatury, było $W$ cieniu Lorelei. Antologia wierszy poetów Republiki Federalnej Niemiec (do roku 1975). Opublikowany przez Wydawnictwo Poznańskie tom ukazał się w 1978 roku $^{31}$. Opracował go oraz wyboru prezentowanych utworów dokonał Stefan H. Kaszyński, wstęp napisał Witold Nawrocki. Do antologii włączono pięć utworów Heinza Piontka, wykorzystując jeden znany już przekład Wilhelma Szewczyka (Rozproszeni). Pozostałe wiersze (Nad Narwiq 1944, Ostrożni, W wodzie, Bardzo stary zdziecinniały poeta $)^{32}$ tłumaczył Alfred Kowalkowski.

31 Pomieszczonych w nim zostało 46 autorów (a zatem w liczbie bardzo zbliżonej do reprezentacji pisarzy uwzględnionych w antologii zachodnioniemieckiej nowelistyki). Poprzez swoje utwory w antologii reprezentowani byli: Hans Arp, Wolfgang Bächler, Heiner Bastian, Jürgen Becker, Gottfried Benn, Max Bense, Horst Bienek, Horst Bingel, Elisabeth Borchers, Nicolas Born, Rolf Dieter Brinkmann, Franz Josef Degenhardt, Friedrich Ch. Delius, Hilde Domin, Günter Eich, Hans Magnus Enzensberger, Ludwig Fels, Walter Helmut Fritz, Günter Bruno Fuchs, Yvan Goll, Günter Grass, Rudolf Hagelstange, Hans-Jürgen Heise, Helmut Heissenbüttel, Günter Herburger, Walter Höllerer, Marie Luise Kaschnitz, Karl Krolow, Wilhelm Lehmann, Christoph Meckel, Ernst Meister, Franz Mon, Helga M. Novak, Heinz Piontek, Johannes Poeten, Arno Reinfrank, Peter Rühmkorf, Nelly Sachs, Wolfdietrich Schnurre, Erasmus Schöfer, Godehard Schramm, Jürgen-Peter Stössel, Dieter Süverkrüp, Jürgen Theobaldy, Volker von Törne, Wolfgang Weyrauch.

32 Oryginalne tytuły wierszy zamieszczone zostały (przy tytułach podanych po polsku) w spisie treści antologii, przy czym zabrakło informacji, z jakich tomów poetyckich Piontka pochodzą. Niniejszym uzupełniam ten brak: Am Narew 1944 (Die Furt, 1952; jest to część druga trzyczęściowego utworu Rückblicke), Die auf der Hut sind (Mit einer Kranichfeder, 1962), Im Wasser (Tot oder lebendig, 1971), Sehr alter törichter Dichter (Klartext, 1966). 
Obecność niemieckiego pisarza ze Śląska dopełniła następna antologia, przygotowana tym razem nie przez germanistów. Tom Poezja XX wieku. Austria, NRD, RFN, Szwajcaria został wydany przez Ossolineum w 1980 roku w wyborze i przekładzie czterech wrocławskich poetów i tłumaczy: Bernarda Antochewicza, Kazimierza Karkowskiego, Tymoteusza Karpowicza i Leona Szweda. Twórczość Piontka reprezentowało w nim również - podobnie jak w poprzednim wyborze - pięć utworów: jeden, Posiłek dróżników, w tłumaczeniu L. Szweda, a kolejne w spolszczeniu K. Karkowskiego: Obłoki, Rozproszeni, Pszczoły i Roczniki33.

Poza utworami zamieszczonymi w antologiach kilka tekstów poetyckich Piontka pojawiło się w latach 70. w tłumaczeniu na łamach czasopism, często w periodykach regionalnych. Katowickie "Poglądy” w 1970 roku zamieściły Ostrożnych w tłumaczeniu Alfreda Kowalkowskiego ${ }^{34}$; w roku następnym w poznańskim „Nurcie” Stanisław Barańczak zamieścił swój przekład wiersza Oderwane istnienie ${ }^{35}$. Nowo założony miesięcznik „Literatura na Świecie” (zob. Pıontek 1972) opublikował (w drugim roku swego istnienia) dwa jego utwory, Rozproszonych ${ }^{36}$ i Baqdź $z d r o ́ w^{37}$, w tłumaczeniu Lucjana Stosio. Pod koniec dekady wiersz Chmury, przełożony przez Bolesława Faca, wydrukował gdański „Punkt”38.

Zatem w prasie literackiej oprócz Piontka nowelisty wprowadzony został również Piontek poeta. Uznać jednak trzeba, że poprzez przekłady obecny był tylko w niewielkim zakresie, pozwalającym jedynie na bardzo ograniczoną identyfikację twórcy w literackiej konfiguracji współczesnej literatury Niemiec Zachodnich. Wydatną pomoc w tym rozpoznaniu stanowiły kompendia adresowane do szerszego kręgu odbiorców: podręcznikowe zarysy historii literatury, słowniki pisarzy, a także krytycznoliterackie tomy szkiców poświęcone (częściowo lub w całości) niemieckiej twórczości literackiej.

${ }^{33}$ Również w tej antologii tytuły oryginalne zaznaczone zostały w spisie treści. Uzupełniam brakujące informacje o tomach poetyckich, z których wiersze pochodzą: Das Mahl der Straßenwärter (Die Rauchfahne, 1953), Wolken (Die Furt, 1952), Die Verstreuten (Wassermarken, 1957), Die Bienen i Jahrgänge (oba zawarte w Tot oder lebendig, 1971).

34 (Piontek 1970c). W oryginale wiersz nosi tytuł Die auf der Hut sind i pochodzi $\mathrm{z}$ tomu Mit einer Kranichfeder (1962).

35 (PiONTEK 1971a). Wiersz, zatytułowany Zurückgenommenes Dasein, pochodzi z tomu Piontka Mit einer Kranichfeder (1962).

${ }^{36}$ W ten sposób Rozproszeni doczekali się trzeciego już tłumaczenia na język polski.

37 Jest to najprawdopodobniej wiersz Valet z tomu Mit einer Kranichfeder (1962).

38 (PIONTEK 1979). Niewiele później wiersz Wolken, przetłumaczony przez A. Kowalkowskiego jako Obłoki, znalazł się w antologii Poezja XX wieku. Austria, NRD, RFN, Szwajcaria. Wybór i przekład B. Antochewicz, K. Karkowski, T. Karpowicz, L. Szwed, wstęp L. Szwed, noty biograficzne K. Karkowski. Wrocław-Warszawa-Kraków-Gdańsk 1980: 404-405. 
Wśród opublikowanych po polsku pełnych syntez piśmiennictwa niemieckojęzycznego największym powojennym przedsięwzięciem były dwutomowe Dzieje literatury niemieckiej. Podręcznik, którego ostatni tom ukazał się w 1972 roku. Właśnie drugi tom podręcznika Mariana Szyrockiego uznany został za „wydarzenie roku w germanistyce polskiej”" Zauważano, że ,autor wyraźnie przesunął punkt ciężkości swego podręcznika na przedstawienie literatury XX wieku", co - zdaniem jednego z recenzentów - miało dwojaką korzyść: „,szersze potraktowanie literatury XX wieku należy uznać za słuszne zarówno ze względu na zainteresowania czytelników, jak i wytyczne programowe Ministerstwa Nauki, Szkolnictwa Wyższego i Techniki” (Hrý́czuk 1975: 109). W Dziejach literatury niemieckiej znalazła się również szczupła, kilkuzdaniowa informacja o Piontku, przy czym stwierdzić należy, iż ta charakterystyka została powtórzona - tym razem w języku polskim - bez większych zmian za wcześniejszym, sygnalizowanym już, skryptem w języku niemieckim Deutsche Lyrik des 20. Jahrhunderts autorstwa Stroki i Szyrockiego ${ }^{40}$. Choć autor syntezy wyraźnie określał zakres czasowy podręcznika („Drugi tom Dziejów literatury niemieckiej przedstawia historię literatury niemieckiego obszaru językowego w okresie od 1830 do 1965 roku"; Szyrocki 1972: 5), wymienione zostały tylko dwa tytuły tomów poetyckich (jedynie z lat 50.) wywodzącego się ze Śląska twórcy, co nie dawało możliwości zapoznania z aktualnym stanem rzeczy. Zgodnie z przyjętym założeniem (nacisk na twórczość, a nie biografie autorów) $)^{41}$ nie pojawiła się nawet wzmianka o rodowodzie pisarza; poza tym Piontek został tu przedstawiony wyłącznie jako poeta, bez najmniejszych odniesień do innych - wówczas już wcale licznych i znaczących - jego dokonań. Mogło to prowadzić do cokolwiek osobliwej i zaskakującej konfrontacji, ponieważ w zamykającym tom aneksie umieszczona została Bibliografia przekładów niemieckiej literatury pięknej na język polski - wybór (do 1968 r.), w której uwzględniony został właśnie tylko Piontek nowelista, autor tomu opowiadań Gorace kasztany.

39 Recenzent Dziejów literatury niemieckiej uzasadniał to następująco: „Pierwszy tom, który ukazał się w 1969 r., nie mógł stanowić tego rodzaju wydarzenia, a to z dwóch względów: 1) okres do roku 1830 (tak bowiem podzielił autor swe Dzieje) mniej interesuje zarówno zwykłych czytelników, jak i znawców; zasadnicze odpowiedzi zostały już tu udzielone, 2) tom drugi przynosi szereg uzupełniających danych, wartościowych samych w sobie" (OrŁOWSKI 1972: 322-323).

40 Jedyna większa zmiana polegała na rezygnacji z przytoczenia jednego z wierszy jako ilustracji liryki Piontka.

${ }^{41}$, „...] w centrum jego [autora - K.P.] zainteresowania znajdują się dzieła literackie, a nie sylwetki twórców" (SzYrocKi 1972: 5). 
Pomocami podręcznymi, przydatnymi zarówno w użytku szkolnym, jak i akademickim (choć ich użyteczność nie ogranicza się jedynie do potrzeb dydaktycznych), mogącymi liczyć na stałe zainteresowanie odbiorców, są słowniki pisarzy. Osobno literaturze niemieckiego obszaru językowego poświęcony został Mały słownik pisarzy niemieckich, austriackich $i$ szwajcarskich - dzieło polskich germanistów, przygotowane pod redakcją Jana Chodery i Mieczysława Urbanowicza i wydane drukiem w 1973 roku. Pierwszą taką próbę podjął ponad dziesięć lat wcześniej Wilhelm Szewczyk, zamieszczając na końcu swojej Literatury niemieckiej $w$ XX wieku -Stownik wspótczesnych pisarzy niemieckich. O ile w tamtym wypadku było to dzieło jednej osoby, o tyle w opracowywaniu haseł wziął udział cały zespół historyków literatury niemieckojęzycznej, głównie z ośrodka poznańskiego (Jan Chodera, Stefan H. Kaszyński, Aleksandra Łukomska-Woroch, Urszula Michalska, Ryszard K. Nitschke, Hubert Orłowski, Edyta Połczyńska, Ludmiła Sługocka, Cecylia Załubska) i wrocławskiego (Konrad Gajek, Eugeniusz Klin² ${ }^{42}$ Anna Stroka, Marian Szyrocki i zmarły przed oddaniem słownika do druku Mieczysław Urbanowicz), a także osoba niezwiązana bezpośrednio z uniwersytecką germanistyką (Emilia Bielicka $)^{43}$ - i to właśnie ona przygotowała hasło dotyczące Heinza Piontka. Można uznać, że zredagowany przez nią słownikowy biogram wnosił niewiele nowego $\mathrm{w}$ stosunku do informacji dostępnych już $\mathrm{w}$ haśle Słownika współczesnych pisarzy niemieckich Szewczyka, a tym bardziej zawartych w jego artykule. Obecna w haśle próba charakterystyki twórczości wypadła chyba zbyt ogólnikowo, by móc określić oryginalność i swoistość dokonań Piontka ${ }^{44}$. Trzeba stwierdzić, że autorka nie zadbała

${ }^{42}$ Eugeniusz Klin, związany w początkowym okresie swej kariery akademickiej z Uniwersytetem Wrocławskim, w czasie powstawania Słownika organizował - od 1969 roku - germanistykę na Uniwersytecie Mikołaja Kopernika w Toruniu, później zaś (od 1978 roku) tworzył i prowadził germanistykę w Wyższej Szkole Pedagogicznej w Zielonej Górze.

43 Emilia Bielicka od początku pracy zawodowej, od 1951 roku, pracowała w redakcji literatur niemieckojęzycznych, skandynawskich i niderlandzkiej w Spółdzielni Wydawniczej „Czytelnik” (w 1969 roku objęła kierownictwo tego działu); równolegle uprawiała twórczość tłumaczeniową z języka niemieckiego (zob. BIELICKA 1988). W jednym z dokumentów Ministerstwa Bezpieczeństwa Państwowego (Ministerium für Staatssicherheit) byłej NRD na temat sytuacji w Polsce na początku lat 80., po wprowadzeniu stanu wojennego, w którym przedstawiona została sytuacja w środowisku twórców kultury związanych z PZPR, E. Bielicka wymieniona jest jako jedna ze „starych sprawdzonych towarzyszy”, którzy w warunkach presji społecznej „odmawiają podjęcia inicjatywy politycznej, zrobienia czegoś dla połączenia sił postępowych”, którzy „boją się, że znajdą się na »czarnych listach", obawiają się o własną egzystencję" (zob. MATKowsKa/ POLECHOŃSKI/RZESZOTNIK 2017: 142).

44 „Zarówno poezję, jak i prozę P.[iontka] cechuje wysoki kunszt formalny (jego opowiadania posiadają konstrukcję niemal klasycznej noweli), duża wrażliwość zmysło- 
o aktualizację danych bibliograficznych (chronologicznie ostatnie z wymienionych dzieł to powieść Die mittleren Jahre z 1967 roku, lecz ostatni z wymienionych tomów wierszy to Wassermarken z $1957 \mathrm{roku})^{45}$; nie ustrzegła się również błędów - nie wiadomo dlaczego, ale najwyraźniej mylnie, przypisała pisarzowi zbiór opowiadań pt. Rote Pfeile ${ }^{46}$.

Można uznać, że zainteresowanie polskich germanistów Piontkiem od początku nie było szczególnie silne i nie przejawiło się w wyraźniejszy sposób. Poeta z Kluczborka w ich pracach pojawiał się przeważnie marginalnie, a kolejne prezentacje wnosiły niewiele nowego do nakreślonego już wcześniej (w latach 60.) obrazu. Tym sposobem Piontek nie zyskiwał, ale stopniowo tracił. Ponieważ brakowało nowych elementów, budujących jego wizerunek, a także nowych, pogłębionych i pełniejszych, odczytań jego dzieła, artysta zastygł w schematycznym, niegdyś nakreślonym konterfekcie. Jego rozwijająca się harmonijnie twórczość w zasadzie nie była zauważana.

Norbert Honsza, kierujący od 1970 roku, to jest od chwili założenia, w Instytucie Filologii Germańskiej Uniwersytetu Wrocławskiego Zakładem Literatury i Kultury Współczesnej Niemiec, Austrii i Szwajcarii, przejawiał zainteresowanie współczesnością literacką podzielonych Niemiec równolegle $\mathrm{w}$ akademickich skryptach oraz na łamach prasy kulturalnej. To, co było przedmiotem skryptów napisanych po niemiecku, pojawiało się $\mathrm{w}$ tym czasie również $\mathrm{w}$ publikacjach Honszy w języku polskim, o przeważnie informacyjno-popularyzatorskim charakterze, ogłaszanych na łamach krajowej prasy (głównie w „Kulturze”, „Odrze”, „Poglądach”, „Spojrzeniach”, „Wiadomościach”, „Życiu Literackim”). Swoją rolę zaangażowanego publicysty, eksponującego polityczny wymiar literatury, postrzegał najwidoczniej na wzór Wilhelma Szewczyka.

wa, zwłaszcza wizualna (P.[iontek] świetnie oddaje piękno krajobrazu), subtelna znajomość psychiki ludzkiej (pisze o ludziach samotnych, wykolejonych, którzy nie potrafią przystosować się do warunków, jakie stworzyło im życie). Cechą charakterystyczną jego utworów jest częste stosowanie retrospekcji oraz skrótów metaforycznych” (E.B. 1973).

45 Według danych zamieszczonych na końcu w metryczce wydawniczej druk $M a-$ łego słownika pisarzy niemieckich, austriackich i szwajcarskich ukończono w styczniu 1973 roku, a oddano go do składania 5.02.1972. Jeżeli ostatnia z zaznaczonych publikacji płodnego pisarza, jakim był Piontek, pochodzi z 1967 roku, widoczny jest brak utworów przynajmniej z paru następnych lat, poprzedzających zamknięcie prac nad słownikiem.

${ }^{46} \mathrm{~W}$ każdym razie nie odnotowuje tego tytułu (jako osobnego tomu opowiadań) bibliografia M. Hollendra (2000). W dorobku Piontka istnieje co prawda opowiadanie Rote Pfeile, które wydrukowano po raz pierwszy w antologii Neunzehn deutsche Erzählungen (München 1963), następnie w Deutsche Erzählungen aus zwei Jahrzehnten (LANGENBUCHER Hg. 1966); tekst ten wszedł również do zbioru nowelistycznego Die Erzählungen (1950-1970) (PIONTEK 1971a). 
Jako jeden z przykładów można przywołać jego artykuł drukowany we wrocławskim tygodniku „Wiadomości”, w którym wspomniany został marginalnie również Heinz Piontek. W 1970 roku, pisząc o Prądach literackich $w$ NRF, Honsza odnosił się krytycznie do niektórych wypowiadanych podówczas opinii:

Jakoś nam trudno jednak podzielić optymizm Wacława Sadkowskiego w odniesieniu do tej literatury, że dąży ona w swej znacznej części do potępienia hitleryzmu i faszyzmu i pragnie humanistycznego odrodzenia narodu niemieckiego. Nie negując autentycznych treści humanistycznych niektórych autorów (Enzensberger, Piontek, Koeppen), dostrzegamy u wielu pisarzy uwiąd i ciasnotę myśli.

HonsZa 1970

Germanista kończył swój wywód: „Argumenty na rzecz humanistycznej wizji świata rodzą się w zachodnioniemieckim środowisku literackim z dużymi oporami” (Honsza 1970).

Inne przeznaczenie, choć podobny charakter, miały prace Honszy adresowane do studentów germanistyki. Opublikowany po niemiecku w 1974 roku jako skrypt Uniwersytetu Wrocławskiego zarys Zur literarischen Situation nach 1945 in der BRD, in Österreich und in der Schweiz szybko doczekał się wznowienia pod zmienionym tytułem Literatur der Gegenwart. BRD - Österreich - Schweiz ${ }^{47}$. Został w nim wymieniony również Piontek. Natomiast wydane na początku 1975 roku kompendium Ksztatt i struktura uznać można za adresowaną do nieco szerszego kręgu odbiorców w Polsce wersję Zur literarischen Situation nach 1945 tudzież Literatur der Gegenwart, ponieważ w zasadzie - zarówno pod względem układu treści, jak i zawartości - jest ono polskojęzycznym odpowiednikiem tych publikacji (a właściwie jednej pozycji, wydanej dwukrotnie pod różnymi tytułami ${ }^{48}$. Heinz Piontek przedstawiony zo-

${ }^{47}$ Mimo zmiany tytułu w drugim wydaniu treść tekstu nie została zmieniona. Zaznaczał to autor w uwagach wstępnych: „Der neue Titel ist eine unveränderte Version der ersten Auflage, obwohl manche Interpretationen teilweise schon überholt sind und etliche Bereiche durch Erkentnisse der siebziger Jahre erweitert werden müßten. Das wird gelegentlich in einer veränderten und erweiterten Auflage geschehen" (HonszA 1976: 5).

48 Zależności pomiędzy dwoma tytułami, Zur literarischen Situation nach 1945... oraz Kształtem i struktura, precyzował Hubert Orłowski w swym zbiorczym omówieniu obu pozycji w „Studia Historica Slavo-Germanica”. Te dwie publikacje uznał on za językowe wersje jednej i tej samej pracy; wersja polska jest według jego obliczeń w około 90-95\% bezpośrednim tłumaczeniem; poza tym pewne fragmenty uległy rozszerzeniu, a tytuły niektórych rozdziałów, a nawet tytuł całej książki (ten - zdaniem Orłowskiego - niestety cokolwiek niefortunnie), zostały przeformułowane. Przytoczenia wart jest odnośny passus przywołanej recenzji: „Es handelt sich hier um zwei sprachliche Fassungen 
stał przez Honszę dwojako: jako komentator i systematyk nowych zjawisk w poezji współczesnej oraz jako czynny poeta, stawiany pośród wybitnych twórców zachodnioniemieckich. Uwzględniwszy nawet wymóg lapidarności, charakterystyki Honszy rażą niekiedy brakiem spójności, upraszczającymi ocenami, sprawiają wrażenie zbyt pośpiesznie napisanych. Według niego Piontek - podobnie jak przedstawiany bezpośrednio przed nim Walter Höllerer -

nie chciałby trwać przy jednym tylko sposobie pisania. Liryka natury, do której się początkowo zwrócił (Die Furt - 1952, Die Rauchfahne 1953), wydała mu się później mało inspirująca. Nadawanie rzeczywistości cech magicznych widzimy jeszcze wyraźnie w wierszu Abends im Gehölz w tomiku Die Furt. [...] W latach pięćdziesiątych zauważyć można nawrót do ballady. Proces ten doprowadził Piontka do wiersza narracyjnego, jak nazwał on nowoczesną balladę. Widać to wyraźnie w jego antologii Neue deutsche Erzählgedichte (1964). Konwencjonalna, świadomie banalna tematyka przypomina nam romancę. Niestety, jego językowe środki wyrazu ponoszą niekiedy porażkę, gdyż dochodzą do konwencjonalnej metaforyki.

Honsza 1975: 294-29549

Przykładem wczesnej liryki Piontka był wspomniany utwór Abends im Gehölz, zamieszczony w spolszczeniu Bernarda Antochewicza (w tłumaczeniu noszący tytuł $W$ lesie o zmierzchu).

Parę lat później dojdzie do tego kolejna publikacja, wydana po polsku i również przeznaczona przede wszystkim dla studentów (choć ze względu na język publikacji, a także sposób ujęcia chyba nie wyłącznie dla germanistów $\left.{ }^{50}\right)$, Szkice z literatury niemieckiej XX wieku wspólnego

(deutsche und polnische) einer und derselben Arbeit. Norbert Honsza hat die beiden Fassungen geschrieben, um zwei verschiedene Lesergemeinschaften zu erreichen: 1. die Studenten der Germanistik in Polen, 2. breitere Leserschichten, die sich für deutschsprachige Literatur der Gegenwart interessieren und bisher über keine entsprechende Informationsquellen verfügten. Es war hier die Rede von zwei sprachlichen Fassungen einer und derselben Arbeit, denn eine Übersetzung im engeren Sinne des Wortes ist es nicht. Etwa 90-95\% der Arbeit ist direkte Übersetzung, manche Passagen wurden jedoch erweitert. Außerdem formulierte Norbert Honsza manche Kapitelüberschriften um. Ja, selbst der Titel der polnischen Fassung wurde (leider etwas unglücklich) umformuliert" (OrŁowsKi 1976: 244).

49 Uwidaczniają się niekiedy niezręczności (własnego?) przekładu. W wersji niemieckiej dwa ostatnie zacytowane zdania mają następującą postać: „Die konventionelle, absichtlich banale Thematik erinnert uns an die Romanze. Leider scheitern manchmal seine sprachkünstlerische Ausdrucksmittel, weil sie in eine konventionelle Metaphorik münden" (HoNsza 1974: 201).

${ }^{50}$ Karol Koczy, recenzując tom Szyrockiego i Honszy, konstatował, iż „dwaj popularni germaniści wrocławscy wydali w oficynie uniwersyteckiej szkice z literatury 
autorstwa Mariana Szyrockiego i Norberta Honszy (opublikowane w serii „Germanica Wratislaviensia”). Przedmiotem tej prezentacji oprócz dwudziestowiecznych dzieł wcześniejszych, sprzed 1945 roku, były dokonania literatury powojennej, głównie zachodnioniemieckiej, a także szwajcarskiej, austriackiej i wschodnioniemieckiej. W rezultacie tego połączenia wyszedł tom o niejednolitej strukturze. Autorem szkiców o niemieckojęzycznej epice pierwszej połowy XX stulecia był Szyrocki, koncentrujący się na charakterystyce wybranych dzieł (Buddenbrookowie, Szaleniec boży Emmanuel Quint, Zamek, Wilk stepowy, Berlin Alexanderplatz, Siódmy krzyż), wpisanych w sylwetki pisarskie swoich twórców (T. Mann, G. Hauptmann, F. Kafka, H. Hesse, A. Döblin, A. Seghers), natomiast o nowszych zjawiskach pisał Honsza. Ta część, pod względem objętości nieco większa, zawierała także rozdziały przekrojowe (między innymi Socjologia ruchu literackiego $w$ RFN, Fragmenty szerokiej panoramy, Literatura masowa $w$ RFN, Beat - pop - underground) oraz - w uzupełnieniu do niektórych portretów - rozmowy z pisarzami: H. Böllem, G. Grassem i M. Walserem. W obszerniejszych charakterystykach oprócz wymienionych twórców - pojawili się również U. Johnson oraz S. Lenz. Zaznaczyć należy, że zamieszczone w omawianym tomie szkice nie ograniczały się do literatury zachodnioniemieckiej, ponieważ prezentacja obejmowała również powojenną literaturę Szwajcarii (M. Frisch), Austrii (T. Bernhard) i NRD (rozdział końcowy, zatytułowany Zaufanie do ludzi i czasu). Właśnie wśród Fragmentów szerokiej panoramy znalazł miejsce autor Goracych kasztanów. Honsza wprowadzał go, zaznaczając przyjęte kryteria wartościowania:

Najwyżej cenimy w literaturze RFN-owskiej te utwory, które próbują oddać społeczne nastroje epoki i są w jakimś stopniu - jak to określa marksistowskie literaturoznawstwo - socjologicznym ekwiwalentem zjawiska literackiego. Są to najczęściej utwory podejmujące żywotną problematykę obrachunku z niemiecką współczesnością. W tej grupie pisarzy znajdziemy mało znanego w Polsce znakomitego poetę Heinza Piontka, który podjął $\mathrm{w}$ swej poezji ton polemiczny $\mathrm{z}$ nacjonalistycz-

niemieckiej XX wieku - zapewne dla nieco szerszego kręgu niż tylko akademickiego” (Koczy 1978: 137). Krystyna Lisowska twierdziła: „Tom ten, chociaż pomyślany głównie jako podręcznik dla studentów, jest dzięki odbiegającej od akademickich schematów formie, w jakiej zaprezentowano poszczególnych pisarzy, ich twórczość oraz zjawiska w literaturze niemieckiej, godną polecenia pozycją dla czytelnika, interesującego się literaturą niemiecką" (LISOwSKA 1978: 134). Andrzej Ubysz oceniał nawet, że „Szkice $z$ literatury niemieckiej XX wieku przeznaczone są zarówno dla studentów germanistyki, którym dostarczają skondensowanej wiedzy na temat wymienionych autorów i trendów, jak też dla szerokich rzesz czytelników interesujących się współczesną literaturą niemieckiego obszaru językowego" (UBYsz 1978). 
nymi mitami wschodnimi. Między innymi wystąpił z interesującą prozą Vor Augen, Die mittleren Jahre oraz ciekawymi słuchowiskami: Der weisse Panther, Freunde in Sodom, Vor Robinsons Insel.

SZYrocki/HonsZa 1978: 118

Najwyraźniej wrocławski germanista podążał szlakiem wytyczonym wcześniej w polskiej krytyce literackiej, korzystając nawet z ocen autora, z którego zdaniem wówczas się liczono:

Proza Piontka jest wolna od nachalnych tez i autorytatywnych rozstrzygnięć, bowiem autor - jak słusznie pisze Wilhelm Szewczyk „wystrzega się publicystyki. Nie ma u niego bezpośredniego oskarżenia przyczyn, które to »coraz cieńsze powietrze« na Śląsku spowodowały[,] cień [sic! - wyraz zniekształcony, właśc.: ani - K.P.] nienawistnej, antypolskiej aury, jakże częstej w literackich elukubracjach, ogłaszanych zwłaszcza na łamach licznych pism ziomkowskich".

SZYROCKI/HONSZA 1978: $118^{51}$

Wywodzącego się z Kluczborka twórcę uwzględniła również Ludmiła Sługocka w wydanej w 1975 roku Powojennej zachodnioniemieckiej liryce o Polsce $w$ świetle zaangażowania pisarzy, germanistycznym opracowaniu historycznoliterackim, wpisującym się w tradycję badań rozwijanych w ośrodku poznańskim (można upatrywać w tym ujęciu kontynuację zwłaszcza prac Jana Chodery: Die deutsche Polenliteratur in der Zeit von 1918-1939 i jej polską wersję Literatura niemiecka o Polsce $w$ latach 1918-1939). Autorka wcześniej przygotowała wzmiankowaną już wyżej antologię Über die Grenzen hinaus. Deutsche Polenlyrik seit den Anfängen bis 1965, natomiast w swojej panoramie tematu polskiego w liryce RFN zajęła się między innymi „poezją ojczyźnianą”, tworzoną przez Niemców przesiedlonych z terenów wschodnich, które po II wojnie światowej przypadły Polsce. Pisała, że jej „głównym motywem [...] jest tęsknota za utraconym »rajem «" (SŁUGocka 1975: 29), systematyzując utwory według postawy przyjmowanej przez autorów: „,W pierwszej grupie jest ona [tęsknota za utraconą ojczyzną - K.P.] zaprawiona nienawiścią i chęcią zemsty, w drugiej obliczona jest na litość i łzy czytelnika, w trzeciej objawia się jako uczucie, które jest zrozumiałe, ale które nie powinno zapanować nad rozsądkiem i nad spojrzeniem w realną przyszłość" (SŁUGOcka 1975: 29). We wprowadzonej przez Sługocką systematyzacji twórczość Piontka zaliczyć można do „drugiej grupy liryków

51 W cytacie z Szewczyka wystąpiły usterki - por. SzEwczyK 1962: 311. Niezrozumiała raczej dla czytelnika fraza „coraz cieńsze powietrze” pochodzi z cytowanego przez Szewczyka (we własnym tłumaczeniu) opowiadania Abends im Oderried, zamieszczonego w debiutanckim tomie opowiadań Piontka Vor Augen. 
poezji ojczyźnianej”, w której brak „wyraźnie wrogich akcentów w stosunku do Polski, jest w niej natomiast niezmiennie wyraźna tęsknota za ojcowizną, której kontury coraz bardziej się zacierają i która staje się we wspomnieniach przesiedlonych jakimś elizjum pozbawionym cech realnych" (SŁUGocka 1975: 29). Autorka podawała parę szczegółów z biografii Piontka (przypisując mu mylny rok urodzenia - 1928) oraz cytowała wypowiedź artysty o stosunku do stron ojczystych ${ }^{52}$, w której poeta przyznaje, że wprowadzany przez niego do twórczości Górny Śląsk zostaje poetycko przetworzony i przezwyciężony. Dalej poznańska germanistka wyodrębniła motywy w jego poezji:

Takie właśnie są obrazy Śląska u Heinza Piontka w jego obszernych zbiorach pt. Die Furt (Esslingen 1952) z opisem Kluczborga [sic!] albo Die Rauchfahne (Esslingen 1953) ze wspomnieniem wiosek, które może ze swoimi niemieckimi nazwami już nie istnieją i z porównaniem Wrocławia i Monachium, albo Mit einer Kranichfeder (Stuttgart 1962) z wyliczeniem różnych bezpowrotnie straconych przyjemności dawnych lat, albo też Die Verstreuten ze wspomnieniami ucieczki. Z rzadka tylko pojawiają się u Piontka uwagi krytyczne, gdy np. w poemacie Erstandene Stimmen ${ }^{53}$ po przeprowadzeniu rzutu historycznego autor zapytuje, z czyjej winy nastąpiło przesiedlenie, albo gdy gani ciągłe nawracanie do przeszłości u przesiedlonych, którzy winni raczej zacząć nowe życie i cieszyć się nim, choć ono w porównaniu z dawnym jest tak nieważkie jak rozwiewający się na wietrze „pióropusz dymu" nad ogniskiem pasterza. Raz tylko w wierszu Erinnerung vom Abschied $^{54}$ Piontek stawia pointy swego obecnego życia: „mój czas, moja żałoba, moja sprawiedliwa strata".

SŁUGOCKA 1975: 36-37

Ten element pozwalał poetę umieścić wśród twórców o innej orientacji na sprawy utraty ziemi rodzinnej: „W tych, chociaż nielicznych, uwagach krytycznych Piontek kwalifikuje się do trzeciej grupy pisarzy poezji ojczyźnianej. Jego liryka znajduje się więc na pograniczu sta-

52 Zapewne Sługocka sporo zawdzięcza wcześniejszym ustaleniom Szewczyka, chociaż przytaczając ten sam autokomentarz Piontka na temat sposobu posługiwania się sferą realiów i faktów podaje go we własnym tłumaczeniu i czerpie z innego źródła (Lubos 1961: 79) niż Szewczyk, który cytował wypowiedź poety z jego listu za Karlem Schodrokiem w kwartalniku „Schlesien” (1957, nr 4). Por. SŁugocKa 1975: 36; SzewCZYK 1962: 306.

53 Ośmioczęściowy poemat Erstandene Stimmen został wydrukowany w tomie Wassermarken (1957).

${ }^{54}$ Zapewne pomyłka autorki. W tomie Die Rauchfahne znajdują się wiersze o zbliżonych tytułach: Erinnerte Landschaft oraz Romanzen vom Abschied, brak natomiast tytułu Erinnerung vom Abschied. 
nowiska marzycielskiego i realistycznego" (SŁUGocka 1975: 37). Można dodać, że zwrócił na to uwagę recenzent pracy Sługockiej, który zaznaczał, że „głosy rozsądku, próby godzenia się z realiami politycznymi i obalania mitów pojawiają się w poezji przesiedleńców rzadko. (Do tych nielicznych, którzy wyzwolili się od mitologii byłych przesiedleńców, należą m.in. Horst Bienek i Heinz Piontek)" (BARTos 1976: 349).

W 1977 roku na łamach poznańskiego „Nurtu” podjął Rozważania nad poezja NRF Stefan Kaszyński. Mimo że artykuł ilustrowały fotografie pięciu poetów, wśród nich Piontka (obok Marie Luise Kaschnitz, Hansa Magnusa Enzensbergera, Ernsta Meistra i Karla Krolowa), w tekście był on jedynie przywoływany. Nie znalazł również miejsca $\mathrm{w}$ towarzyszącym artykułowi małym wyborze wierszy zachodnioniemieckich poetów, udostępnionych w polskim przekładzie (znaleźli się w nim Hans Magnus Enzensberger, Yvan Goll, Volker von Törne, Gottfried Benn, Karl Krolow, Günter Grass i Ernst Meister). Poznański germanista kreślił uwarunkowania poezji zachodnioniemieckiej, stosunek do tradycji literackiej, sygnalizował główne tendencje i kierunki jej rozwoju. Odnotowywał obecność Piontka w kontekście „wpływów egzystencjalizmu, szczególnie w jego Jaspersowskiej wersji”, pisząc, że

z tych też pozycji Kaschnitz, Eich, Krolow, Weyrauch, Schnurre, Hagelstange i Piontek dokonywali rozrachunku z przeszłością zarówno na płaszczyźnie narodowej, jak i osobistej. [...] Obrachunek z przeszłością przebiega na różnych piętrach poetyckiej świadomości, u niektórych będzie to bezpośredni zapis przeżyć wojennych (Piontek Am Narew ${ }^{55}$ ), u innych reminiscencja z dzieciństwa (Bienek Gleiwitzer Kindheit), u jeszcze innych projekcja obrazów z przeszłości w teraźniejszość (Grass Kleckerburg).

KASZYŃSKI 1977: 20

Kaszyński dodawał do tego podejmowany przez poetów Republiki Federalnej temat polski:

Do grupy tekstów obrachunkowych można by zaliczyć też owe nieliczne, lecz ważkie wiersze o tematyce polskiej. W lirykach takich autorów jak Benn, Grass, Rainfrank, Piontek, Bienek, von Törne Polska z jej krajobrazem i przeszłością staje się sama w sobie lirycznym podmiotem. [...] Oczywiście temat polski jest dla każdego z wymienionych pisarzy bardzo intymną sprawą osobistej rezygnacji, lecz równocześnie apelem do politycznego rozsądku swych rodaków.

KASZYŃSKI 1977: 20

55 Utwór pod właściwym tytułem Am Narew 1944 był środkową częścią trzyczęściowego utworu Rückblicke (z tomu Die Furt, 1952). 
W dalszych wywodach Piontek już się nie pojawił, zatem w nakreślonej konstelacji poetyckiej Niemiec Zachodnich był jednym z wielu liczących się nazwisk, ale najwidoczniej nie był traktowany jako ten, który nadawał ton ówczesnej liryce RFN.

Nieco zaskakującym, choć niewątpliwie jednym z najważniejszych polskich świadectw odbioru twórczości „poety z Kluczborka” był opublikowany w „Twórczości” wnikliwy, analityczny szkic Henryka Berezy pt. Proza Heinza Piontka. Krytyk zaczynał swoje uwagi od wyodrębnienia indywidualności Piontka jako zachodnioniemieckiego prozaika:

Swoją pozycję pisarską zawdzięcza Heinz Piontek [...] bardziej poezji niż prozie. Jego proza nie ma cech takiej niezawisłości artystycznej, jaką ma proza Martina Walsera, nie mówiąc już o prozie Güntera Grassa. Piontek należy chyba do tych poetów, którzy - jak u nas Julian Przyboś - prozę uważają za coś zasadniczo różnego od poezji, jest to dla nich - prawdopodobnie - klasyczna różnica między supremacją świata wewnętrznego człowieka nad jego światem zewnętrznym, oznacza to konflikt ze znamienną tendencją nowej prozy, która świat zewnętrzny człowieka maksymalnie interioryzuje.

BerEZA 1977: 137

Dopowiadał przy tym: „Mitotwórcą czy mitorobem Heinz Piontek nie jest i nie może być, ponieważ jest to pisarz, dla którego liczy się tylko czas teraźniejszy człowieka, jego aktualna sytuacja w świecie zewnętrznym" (Bereza 1977: 137). Dodawał także:

Proza Piontka w znanych mi utworach demonstruje ciągłą niewygodę usytuowania człowieka w świecie zewnętrznym i w teraźniejszości. Ucieczki nie udają się, a z jakichś względów nie bierze się pod uwagę możliwości odwrotu, powstaje więc konieczność stałej kontynuacji ucieczek od domów, od ludzi, od jednej prowizoryczności w drugą, jeszcze bardziej prowizoryczną.

BEREZA 1977: 137-138

Bereza swoje uwagi o prozie Piontka formułował na podstawie opowiadań z tomów Vor Augen i znanego w polskim przekładzie Kastanien aus dem Feuer oraz nieomawianej dotąd w Polsce powieści Dichterleben. Czynił przy tym spostrzeżenie: „Prozy Heinza Piontka może dlatego tylko nie należy przegapić, że jest on tak niezwykle wyczulony na wszelakie społeczno-egzystencjalne niewygody sytuacji człowieka pióra" (BEREza 1977: 138). W Goracych kasztanach za najlepsze opowiadania uważał krytyk Niełatwa sprawę i Zrównanie dnia z noca; jego zdaniem 
obydwa utwory zapowiadają tę diagnozę sytuacji egzystencjalno-społecznej człowieka pióra, jaką Piontek stawia w wersji powieściowo rozbudowanej w Dichterleben (1976). [...] W opowiadaniu Niełatwa sprawa można by widzieć szkic wstępny do powieści Dichterleben. Czterdziestoletni Martin Wittmar uświadamia sobie, jeszcze buntując się, to, z czym pięćdziesięciolatek Achim Reichsfelder musiał pogodzić się i pogodził się całkowicie: w literaturze klęska zaczyna się już w momencie sukcesu, jeżeli zdążyło się go dostąpić, sukces jest stałą szansą nowych i młodych, jest to szansa zarezerwowana dla trzydziestolatków, konkurencji z nimi starsi nie wytrzymują, pozostaje im rola zabytku w muzeum literatury. Martin Wittmar buntuje się przeciwko tej roli, jeżdżąc z samozaparciem na sesje, sympozja i kongresy.

BEREZA 1977: 138

Dochodząc do analizy powieści, Bereza poświęcił jej sporo przenikliwych uwag i zamykał swój szkic następującym podsumowaniem:

Heinz Piontek jest w prozie realistą społecznym typu raczej balzakowskiego niż cervantesowskiego. Los Achima Reichsfeldera nie jest literacką metaforą, jest socjologiczną konstrukcją, w której wykorzystuje się własne doświadczenia i własne obserwacje stosunków społeczno-kulturalnych $\mathrm{w}$ dobrze znanym sobie świecie. Od aluzji cervantesowskich i innych ciekawsze są w Dichterleben niezliczone wzmianki (z nazwiska) o znanych postaciach zachodnioniemieckiego życia literackiego. Pada nawet wzmianka o samym Piontku, co ma może przeciwdziałać doszukiwaniu się $\mathrm{w}$ utworze treści autobiograficznych.

Doszukiwać się w tej powieści bezpośredniego autobiografizmu byłoby naiwnością. Piórem Heinza Piontka włada w prozie wzrok zewnętrzny, nie wewnętrzny, wzrokiem zewnętrznym siebie można zobaczyć tylko przez lustro i tylko zewnętrznie. Piontkowi to wystarcza, każe on Reichsfelderowi widzieć w sobie tylko to, co widzą w nim inni.

Dla człowieka pióra jest to miara szczególnie okrutna. Okrucieństwo tej miary sprawia, że powieści Dichterleben nie można zlekceważyć, choć literacko jest to utwór, który nikogo niczym nie zdoła ani artystycznie olśnić, ani intelektualnie zbulwersować. Powinno więc wystarczyć, że powieści Dichterleben nie da się czytać bezmyślnie.

BerEza 1977: 139

Po publikacji w „Twórczości” szkic (pod zmienionym tytułem Los człowieka pióra) wszedł do wydanego dwa lata później krytycznoliterackiego tomu Henryka Berezy Proza z importu (Bereza 1979).

W tym czasie w wydawanym w RFN kwartalniku „Begegnung mit Polen" Stanisław Wilczek, współpracownik i członek redakcji katowickich „Poglądów”, przedstawiał niemieckiemu czytelnikowi „cztery pokolenia niemieckich pisarzy z Polski”. Tytuł (Vier Generationen deut- 
scher Schriftsteller aus Polen) mógł być mylący, ponieważ mowa była wyłącznie o autorach wywodzących się z Górnego Śląska - reprezentację stanowili Max Ring, Hans Marchwitza, Wilhelm Tkaczyk oraz Heinz Piontek. Wśród prezentowanych przykładów ostatni „reprezentuje to pokolenie niemieckojęzycznych pisarzy ze Śląska, którzy opuścili swoje strony rodzinne, spędziwszy tu tylko dzieciństwo i młodość" (WILczek 1978: 22). Skrótowa charakterystyka Piontka ograniczała się właściwie do podstawowych informacji; Wilczek nie wychodził w zasadzie poza stwierdzenia Wilhelma Szewczyka (zawarte w jego Literaturze niemieckiej wXX wieku), na którego się zresztą powoływał. Podobnie jak Szewczyk podnosił, że twórczość Piontka nie służy celom rewizjonistycznej propagandy ${ }^{56}$.

Końcowa dekada PRL-u nie spowodowała przełomu w polskiej recepcji Heinza Piontka. Można notować wtedy raczej pogłębiający się brak zainteresowania tym pisarzem, stopniowe zapominanie i jego marginalizację. Zainteresowanie literaturą niemiecką dotyczyło twórczości zupełnie innych autorów. Niejako przy okazji eksploracji dotychczas nieufnie traktowanych tematów „literackie powroty” niemieckich pisarzy na utracone po II wojnie światowej ziemie rodzinne przypomniała w 1986 roku w obszernym artykule Ilona Mazurska. Wśród licznej reprezentacji twórców - od wywodzących się z Prus Wschodnich S. Lenza i A. Surminskiego, przez gdańszczanina G. Grassa, pochodzącą z dzisiejszego Gorzowa Wielkopolskiego Ch. Wolf, po Ślązaków Janoscha, W. Haiduczka i H. Bienka - znalazło się również miejsce dla Piontka. Pisarz zaprezentowany został w sposób niezbyt obszerny (i dość powierzchownie), jedynie jego wczesna proza zyskała zainteresowanie:

Autorem zbioru opowiadań Vor Augen, 1955 (Przed oczyma) jest zachodnioniemiecki poeta i prozaik Heinz Piontek pochodzący z Kluczborka. W swojej książce zajmuje się tematyką śląską, ale jego opowiadania nie mają charakteru wspomnieniowego. Są to bardzo poetyckie wizje, czasem mroczne, czasem w jaśniejszych barwach, w których realia górnośląskie potraktowane są na ogół dość swobodnie. Piontek daleki jest od odmalowywania „byłej krainy szczęśliwości”. Jego proza przepojona jest jednak mimo wszystko tęsknotą za rodzinną ziemią.

MAZURSKA 1986: $67^{57}$

56 „Doch Pionteks ausgefeilte Gedankengänge in der Dichtung eigneten sich kaum für die revisionistische Propaganda" (WILCzEK 1978: 23).

57 Warto zaznaczyć, że na artykuł Mazurskiej zareagował w „Trybunie Robotniczej” polemicznym tekstem Nostalgiczne powroty - dokąd i po co? Wilhelm Szewczyk. Zauważał, że „brak tutaj podsumowania, wykraczającego poza informacje literackie i pobieżną charakterystykę postaw pisarskich, które zadomowione są przecież nie tylko w samej 
Pod koniec lat 80. zaprezentował Piontka Jan Koprowski w innej niż dotychczas roli - jako antologistę za sprawą ułożonego przezeń tomu Jeder Satz ein Menschengesicht. Schriftsteller berichten über ihren Beruf (1987). Koprowski przypomniał wywodzącego się z Kluczborka poetę, zauważając, że „w Polsce Heinz Piontek jest autorem nieznanym zarówno jako poeta, jak i autor nowel, słuchowisk i esejów, chociaż tłumaczono go dotychczas na 25 języków" (Koprowski 1988) (opinię tę można uznać za odpowiadającą wówczas rzeczywistości, choć recenzent skazał tym samym na zapomnienie opublikowany w Polsce zbiór opowiadań oraz rozproszone przekłady liryki). Wskazywał przy tym, że niemiecki twórca

[...] wydał wiele antologii poezji i prozy, ale obecna antologia Jeder Satz ein Menschengesicht (Każde zdanie to twarz ludzka) ma charakter szczególny. Heinz Piontek zebrał w niej wiele wypowiedzi autorów niemieckich i zagranicznych, dawnych i współczesnych, poświęconych twórczości literackiej i pracy pisarza. Przy pomocy zebranych cytatów próbuje Piontek opowiedzieć, co w różnych czasach twórcy mówili i pisali o swoim zawodzie, jak pisarz żyje, kto, co i dlaczego pisze. Mowa jest $\mathrm{w}$ tej antologii także o szczęśliwych inspiracjach, o nędzy zapomnienia, o blaskach sławy i niedostatkach materialnych sztuki.

KoprowsKi 1988

W tym samym czasie w przeglądzie literatury RFN lat 80 . Norbert Honsza (pośród dokonań roku 1984) odnotowywał, wymieniając jedynie z tytułu, autobiograficzną powieść Piontka Zeit meines Lebens ${ }^{58}$.

Utrzymującego się już kilkanaście lat wyraźnego braku zainteresowania postacią i twórczością twórcy o śląskim rodowodzie nie odwróciły przemiany polityczne, załamanie systemu komunistycznego w Europie Środkowo-Wschodniej, upadek PRL oraz zniesienie cenzury. Przełom polityczny, który nastąpił w Polsce, zdecydowanie nie był przełomem w polskiej recepcji Piontka. Trudno uznać dość przypadkowe publikacje przekładów w czasopismach czy sporadyczne wzmianki o autorze

\footnotetext{
literaturze, ale i w polityce". Jego wątpliwości budziło i naświetlenie przez autorkę pewnych problemów, jak niedostrzeganie autobiografizmu tej twórczości, i nieznajomość uwarunkowań i uwikłań pewnych pojęć, jak zwłaszcza „Heimatliteratur”. Katowicki niemcoznawca kończył swoje uwagi następująco: „Będziemy się zatem musieli w dalszej przyszłości zajmować przede wszystkim pisarzami, którzy mity wschodnioniemieckie obnażają i dla których nostalgia za stronami rodzinnymi, naturalna jak u każdego człowieka, nie jest przeszkodą w ustanawianiu pomostów między Niemcami a Polakami, między RFN a PRL. Oni zresztą wyznaczają także kierunki rozwojowe współczesnej literatury niemieckiej” (SzEWCZYK 1986).

58 (Honsza 1988, przedr. Honsza 1994: 177).
} 
za istotne dokonania $\mathrm{w}$ losach recepcji pisarza z Kluczborka. Za taką okazjonalną publikację, służącą przypomnieniu zapomnianego $\mathrm{w}$ miejscu swego urodzenia twórcy, należy uznać artykuł w języku niemieckim Hanny Stieglitz Heinz Piontek ein Schriftsteller aus Oberschlesien, zamieszczony w wydawanym w Opolu dwujęzycznym dwutygodniku „Oberschlesische Zeitung/Gazeta Górnośląska” (1992, nr 4). Kilka przejawów z ostatniego ćwierćwiecza godnych jest jednak przywołania.

$\mathrm{Na}$ początku lat 90. pojedyncze wiersze Piontka ukazały się w „Res Publice” i „Borussii”"59. W tym czasie niemieckiego autora w rozgłośni polskiej Radia Wolna Europa podczas audycji poświęconej zmarłemu Horstowi Bienkowi, wyemitowanej 16 grudnia 1990 roku, wspominał Włodzimierz Odojewski. Umieszczając autora Pierwszej polki w nurcie niemieckiej „literatury kresowej”, autor Wyspy ocalenia mówił wtedy:

Nazwiska takie jak Horst Bienek, Günter Grass, Siegfried Lenz, Hans Lipinsky-Gottersdorf, Christa Wolf, Hans Kirst, Dagmar von Mutius, Arno Surminski, Heinz Piontek, Graf von Krockow, a wymieniam tylko najznaczniejszych z tej grupy, choć w kręgach inteligencji mogą być znane (i też zresztą nie wszystkie), szerszemu ogółowi Polaków niewiele mówią, mimo że literatura sąsiadów szczególnie powinna interesować, literatura zaś pewnej części tych sąsiadów, której niezwykle powikłane losy sprzęgły się z naszymi losami, że od naszych losów nie można ich nieraz oderwać, powinna interesować jeszcze szczególniej.

ODOJEWSKi 1996: 153-154

Cytowany fragment pochodzi z tekstu wygłoszonego pierwotnie na antenie radiowej, który znalazł się później w wydanym w 1996 roku tomie Odojewskiego Notatnik pótprywatny. Przy tej okazji wyłania się również jeszcze jeden (najmniej udokumentowany i najsłabiej zbadany) wątek recepcji literatury niemieckiej za pośrednictwem zagranicznych rozgłośni radiowych $\mathrm{w}$ audycjach polskojęzycznych (a więc nastawionych na odbiór w Polsce). W poświęconym Horstowi Bienkowi przyczynku Stanisław Bieniasz, emigrant z lat 80., wspominał:

Kiedy podjąłem stałą współpracę $\mathrm{z}$ redakcją polską radia Deutschlandfunk, oczywistym było dla mnie, że zajmę się popularyzowaniem dzieł pisarzy niemieckich, związanych z byłymi, a obecnie polskimi ziemiami. Nie trzeba było popularyzować Güntera Grassa, który był $\mathrm{w}$ Polsce autorem znanym i wydawanym. O pozostałych wiedziano niewiele. Robiłem więc audycje poświęcone Hansowi Lipinsky’emu-

59 Należy odnotować te publikacje: PionTeK 1990 (Einfache Sätze aus dem Jahr 68 $\mathrm{z}$ tomu Tot oder lebendig, 1971); PIONTEK 2004 (Akademie der Schönen Künste z tomu Wie sich Musik durchschlug, 1978). 
-Gottersdorfowi, Heinzowi Piontkowi, Siegfriedowi Lenzowi, Christianowi von Krockow i innym, mniej znanym, przede wszystkim zaś Bienkowi.

W połowie lat 90 . ważnym momentem była publikacja leksykonu Pisarze niemieckojęzyczni XX wieku (1996 [antydat. 1995]) pod redakcją Marka Zybury. Hasło autorstwa redaktora całości przedsięwzięcia było merytorycznie najpojemniejszą z dotychczasowych polskich prezentacji słownikowych. Dostarczało też możliwie aktualnej wiedzy, co w przypadku Piontka było bardzo oczekiwane, ponieważ zaniedbania faktograficzne sukcesywnie narastały od momentu pierwszej całościowej prezentacji, dokonanej przez Szewczyka na początku lat 60. Wymieniając tomy poezji Piontka, Zybura eksponował Klartext (1966) - jako jego „najlepszą jak dotąd książkę poetycką” (Zybura 1996). Wyróżniony został również tom eseistyczny Buchstab, Zauberstab. Poetische Verteidigung des Menschen (1959), „kwestionujący walory uprawianych na modernist.[yczną] modłę eksperymentów jęz.[ykowych] w poezji dla samych efektów formalnych" (Zybura 1996). Zybura sporo miejsca poświęcił prozie narracyjnej Piontka: zbiorom opowiadań (wymienione zostały początkowe Vor Augen i Kastanien aus dem Feuer),

[...] dwóm ściśle autobiogr.[aficznym] powieściom Zeit meines Lebens (1984) i Stunde der Überlebenden (1989), obejmującym okres 19251945" oraz tzw. trylogii monachijskiej (Die mittleren Jahre, 1967; Dichterleben, 1976; Juttas Neffe, 1979), gdzie „tematyczne spektrum współcz.[esnej] problematyki tych utworów rozpięte jest szeroko od zagadnień egzystencji artyst.[ycznej], przez rodzinne konflikty pokoleniowe, po zjawisko terroryzmu i zbrojeń na świecie.

ZYBURA 1996

Leksykon encyklopedyczny PWN informował o popularności słuchowisk, szczególnie Weißer Panther; zwracał również uwagę, że „,w latach 60. P.[iontek] wydał też kilka wartościowych antologii poet.[yckich], m.in. ambitną panoramę tysiąclecia liryki niem.[ieckiej] Lieb, Leid und Zeit und Ewigkeit. Deutsche Gedichte aus tausend Jahren (1968)" (Zyвura 1996).

Dopiero w nowym tysiącleciu udało się zrealizować to, czego nie udało się dokonać przez ponad 40 lat dotychczasowej recepcji. Próbą nadrobienia zaniedbań recepcyjnych było przygotowanie osobnego wyboru tekstów Heinz Piontek - życie i dzieło, prezentującego osobę i twórczość niemieckiego poety i prozaika, wpisane w miejsce jego pochodzenia.

60 (BIENIASZ 1998). Niestety brak bliższych danych wspomnianych audycji radiowych, w których prezentowany był również Heinz Piontek. 
Ten zamiar podkreślają zarówno fotografie zamieszczone w tekście, jak i pierwsza strona okładki, na której znalazła się reprodukcja akwareli autorstwa Piontka przedstawiającej kościół ewangelicki w Kluczborku. Publikacja ukazała się w 2004 roku i najwyraźniej została przygotowana dla upamiętnienia śmierci twórcy, zmarłego jesienią poprzedniego roku (26 października 2003). Tom zawiera opowiadania ${ }^{61}$ i fragmenty tekstów wspomnieniowych (w przekładzie Jana Goczoła) oraz stosunkowo bogaty wybór wierszy ${ }^{62}$ (w tłumaczeniu Andrzeja Lama), stanowiący najobszerniejszą z dotychczasowych prezentacji twórczości poetyckiej Piontka w polskim przekładzie. Dodatkowo - poza tekstami samego Piontka - zamieszczono materiały biograficzne ${ }^{63}$ oraz kalendarium ${ }^{64}$. Pub-

${ }^{61}$ Jak pisze Adolf Kühnemann we wstępie, „w części prezentującej prozę Piontka Czytelnik znajdzie kilka opowiadań z reminiscencjami dotyczącymi różnych okresów jego życia i twórczości" (KüHNEMANN 2004). Oto tytuły zamieszczonych utworów: Niech Bóg będzie dla nas taskawy! [Gnade uns Gott!], Mój aniot [Mein Engel], Na Wschodzie [Im Osten], Rocznik 1925, dzieciństwo Hanka [Jahrgang 1925, Hankes Kindheit], Zamek, jego goście, wojna [Ein Schloß, seine Gäste, der Krieg], Czas przedtem [Die Zeit davor] $i$ Co pan wtedy myślat? [Was haben Sie sich dabei gedacht?]. (KüHNEMANN red. 2004: 29-72).

${ }^{62} \mathrm{~W}$ przekładzie udostępniono ponad 50 utworów z różnych okresów twórczości. Ich układ jest chronologiczny, raczej zgodny z kolejnością tomów poetyckich, w których zostały po raz pierwszy wydrukowane (choć zdarzają się przeoczenia czy niedokładności). Nie są też jasne kryteria wyboru, który najwidoczniej nie kieruje się zasadą proporcjonalności. W części Wiersze umieszczone zostały następujące liryki (tytuły podaję w przekładzie Andrzeja Lama): Na łodzi, Kiedy nadchodzi noc, Zatracona ulica, Goraczka, Przelotne spojrzenie, Ania, Trzydzieści lat, Narzeczona wiatru, Ostrożni, Wspomnienie młodości, Prekursorzy, Czysta jak szkło, W wodzie, Dokąd wiedzie droga, Osobliwe, Drzewa, Śpiew, U Zimmera, Pszczoły, Moja mowa, Największy wyczyn, czyli śnieg, Noca, na budowie Wieży Babel, Kalenica, Coś stworzyć, Tabu językowe, Akademia Sztuk Pięknych, Dwoje pitujacych drewno, Czas innej wyktadni, Na ostatek, Bezpieczna droga, Wspaniałe, Złamane milczenia, Czym jest prawda, Odległość czterdziestu lat, Wschodza gwiazdy północy, Ostatniego roku w Tessin, Nocne pociagi, Młodość, Mieć szczęście, Półcien, Życie mieszkańca wieży, Wyż atlantycki, Początek zimy, Życie poety, inne, „Pamiętam...”, Straż poranna (druga wersja), Ostatnia droga, Już od dzieciństwa..., W cieniu ziemi, Zmiana warty. Ponadto w części początkowej, na którą składają się złożone z tekstów Piontka Migawki z dawnego Kluczborka, znalazły się dwa wiersze: Targ nabiałowy [Kreuzburger Buttermarkt] z tomu Klartext (KüHNEMANN red. 2004: 18) i Utracone miasto [Verlorene Stadt] z tomu Die Rauchfahne (KüHNEMANN red. 2004: 26), zaś w pomieszczonym w tomie okolicznościowym tekście Ludwiga Steinherra cytowane są utwory: $\mathrm{Na}$ todzi [Bootsfahrt], Śpiew [Singen], Drzewa [Bäume], Stuchajac [Zuhörend], Moja mowa [Meine Rede], Czym jest prawda? [Was ist Wahrheit?], Kalenica [Der First], fragment wiersza o Vermeerze [Vermeers Stadt], Noca, na budowie Wieży Babel [Nachts, beim Turmbau zu Babel], Bezpieczna droga [Freies Geleit] oraz fragment poematu Wir setzen auf Fähren über z tomu Neue Umlaufbahn.

${ }_{63}$ FuHRMANN 2004; STEINHERR 2004.

${ }^{64}$ HaAs/FeIlert 2004. 
likacja, wydana przez Konwersatorium im. Josepha von Eichendorffa, mimo że potencjalnie mogła zainteresować szersze grono czytelników, nie wywołała odpowiedniego rezonansu, trafiając raczej tylko do lokalnego i środowiskowego kręgu odbiorców. To samo można powiedzieć o wydawanym przez wymienioną instytucję polsko-niemieckim piśmie mniejszości niemieckiej na Śląsku Opolskim - „Zeszytach Edukacji Kulturalnej/Hefte für Kulturbildung”, które w ostatnim czasie poświęciły Piontkowi relatywnie więcej uwagi ${ }^{65}$. Podobnie rzecz ma się z - również dwujęzycznym - wydawanym w Łubowicach kwartalnikiem "Zeszyty Eichendorffa/Eichendorff-Hefte”, w którym znaleźć można teksty Piontka i o Piontku ${ }^{66}$.

Do polskiej recepcji Heinza Piontka zaliczyć można - acz z uzasadnionymi zastrzeżeniami - artykuły polskich germanistów, publikowane $\mathrm{w}$ języku niemieckim ${ }^{67}$. Wśród nich $\mathrm{w}$ zasadzie wyjątkowo natrafimy na polskojęzyczną publikację ${ }^{68}$. W ostatnich dwudziestu latach obraz polskiej recepcji germanistycznej Piontka jest znaczący, choć naukowa refleksja objęła jedynie wycinek jego twórczości. Wyróżnić należy w niej przede wszystkim dysertacje doktorskie, będące wyrazem zainteresowania niemieckim pisarzem o śląskim rodowodzie. Ich autorzy: Robert Buczek ${ }^{69}$, Emil Feilert ${ }^{70}$ oraz Marek Lotko ${ }^{71}$, w znacznym stopniu przyczynili się do rozwoju w Polsce badań nad twórczością Piont-

${ }^{65} \mathrm{~W}$ czasopiśmie zamieszczano utwory H. Piontka, m.in. pochodzące z tomu Die Erzählungen (1971) opowiadanie Auf Weihnachten zu / Oczekiwanie Bożego Narodzenia (Piontek 2003b), a także teksty jemu poświęcone, np.: DitTMar 2003.

${ }^{66}$ FeILERT 2003b; Piontek 2003a.

${ }^{67}$ Te publikacje dają w sumie całkiem pokaźną liczbę, czego dowodem niech będzie poniższe (niepełne) zestawienie: BuczeK 1996; BuczeK 1998; BuczeK 2002; BuczeK 2003a; BuCZEK 2003b; FeILERT 2003b; Jarosz-SiENKIEWICZ 2013; Jarosz-SienKIEWICZ 2015; JarosZ-Sienkiewicz 2016; Jarosz-SienkIEwicz 2017. Do zestawu związanych z Polską autorów prac naukowych lub popularyzatorskich o H. Piontku dodać trzeba Renatę Szuman-Fikus, przez pewien czas (1980-1983) pracującą jako adiunkt na germanistyce Uniwersytetu Śląskiego, która po wyjeździe do RFN zmieniła - oprócz nastawienia - nazwisko na Schumann (tudzież powróciła do pierwotnej pisowni rodowego nazwiska). Zob. jej artykuły: SCHUMANN 1997; SCHUMANN 1998.

${ }^{68}$ LOTKO 2005.

69 Doktorat Roberta Buczka Autobiographische Aspekte in den Romanen „Zeit meines Lebens” und „Stunde der Überlebenden” von Heinz Piontek, przygotowany w Wyższej Szkole Pedagogicznej w Zielonej Górze pod kierunkiem prof. Eugeniusza Klina, został obroniony na Uniwersytecie Szczecińskim w 2001 roku.

${ }^{70}$ Swą pracę doktorską Das Bild schlesischer Familien in der autobiographischen Prosa von Rotraud Schöne und Heinz Piontek Emil Feilert obronił w 2004 roku na Uniwersytecie Opolskim; jej promotorem była prof. Grażyna B. Szewczyk.

71 Obrona dysertacji Problematyka autobiograficzna $w$ twórczości Heinza Piontka Marka Lotki, napisanej pod kierunkiem prof. Marka Zybury, miała miejsce na Uniwersytecie Opolskim w 2006 roku. 
ka, w szczególności jego prozą autobiograficzną. W Niemczech wyszła książka Buczka Autobiographische Aspekte in den Romanen „Zeit meines Lebens" und "Stunde der Überlebenden" von Heinz Piontek (Frankfurt am Main 2004); po niemiecku opublikowana została także praca Feilerta Heinz Pionteks Romane „Zeit meines Lebens” und „Stunde der Überlebenden" als familiengeschichliche Quellen (Dresden, Wrocław 2010); w języku polskim ukazała się dysertacja Lotki „Wszystkie minione żeglugi wspominam dzisiaj samotnie...". Autobiografizm w twórczości literackiej Heinza Piontka (Opole 2010). Oprócz wydanych drukiem doktoratów docenić trzeba ogłaszane $\mathrm{w}$ języku niemieckim publikacje germanistki z Uniwersytetu Wrocławskiego Ewy Jarosz-Sienkiewicz, zajmującej się głównie liryką oraz w mniejszym stopniu nowelistyką autora Gorących kasztanów.

Można zauważyć, że Piontek jest z reguły uwzględniany w ogólnych kompendiach literackich, takich jak Encyklopedia literatury światowej (Maślanka red. 2005: 842), Literatura świata. Encyklopedia $P W N^{72}$ czy Słownik pisarzy świata (MAślanka red. 2008: 623), przy czym te prezentacje (zazwyczaj w postaci hasła osobowego) nie wychodzą poza najbardziej elementarne informacje. Obecność autora w szerokim kanonie twórców dwudziestowiecznej literatury powszechnej nie świadczy jednak o jego przyswojeniu czy nawet rozpoznawalności przez polskich odbiorców.

Podsumowując dotychczasowe spostrzeżenia, wypada uznać, iż niemiecki pisarz o śląskim rodowodzie nie zaistniał w Polsce we właściwy ze względu na rangę swych dokonań literackich sposób. Można przyjąć, że dzieje jego polskiej recepcji nie są zamknięte, choć jednocześnie nic nie wskazuje na to, że po latach nieobecności (lub co najwyżej niewielkiego zainteresowania) Piontek miałby szansę doczekać się w najbliższej przyszłości intensywniejszej prezentacji, skierowanej zarazem do szerszego kręgu odbiorców. Niewątpliwie dowodem pamięci ze strony polskiej jest okolicznościowa sesja naukowa, zorganizowana $\mathrm{w}$ piętnastolecie śmierci Heinza Piontka w miejscu jego urodzenia ${ }^{73}$. Owocem konferencji z pewnością będzie publikacja tomu, zawierającego wygłoszone $\mathrm{w}$ języku niemieckim referaty oraz zamówione teksty. Czas pokaże, jak dalej rozwiną się próby przybliżenia niemieckiego poety z Kluczborka polskim czytelnikom przez tłumaczy, krytyków i badaczy literatury...

72 Literatura świata 2007: 560.

${ }^{73}$ Dwudniowa konferencja „Wacholderdschungel gibt mich frei”. Heinz Piontek (1925-2003) als Literat, Kritiker und Mensch (Kluczbork, 20-21.09.2018 rok) zorganizowana została przez Instytut Filologii Germańskiej Uniwersytetu Wrocławskiego. 


\section{Literatura}

50 opowiadań Niemieckiej Republiki Demokratycznej. Antologia. Poznań: Wydawnictwo Poznańskie 1974.

b [= Krońska Irena] (1970): Przegląd zagraniczny. Austria. W: Twórczość nr 6: 137-138.

Bartos Krzysztof (1976): O Polsce w zachodnioniemieckiej poezji. W: Literatura na Świecie nr 7: 347-350.

Bereza Henryk (1977): Proza Heinza Piontka. W: Twórczość nr 10: 137-139.

Bereza Henryk (1979): Los człowieka pióra. W: Idem: Proza z importu. Szkice literackie. Warszawa: Czytelnik: 93-97.

BIALIK Włodzimierz (1975): Układ znaczacy. W: Literatura nr 36: 6.

BIELICKA Emilia (1988): Die Verlagspraxis einer Lektorin. In: KNEIP Heinz/ORŁOWSKI Hubert (Hg.): Die Rezeption der polnischen Literatur im deutschsprachigen Raum und die der deutschsprachigen in Polen 1945-1985. Darmstadt: Deutsches Polen-Institut: 473-477.

Bieniasz Stanisław (1998): Horst Bienek - jeden z nas. W: Śląsk nr 10: 23-24.

BuczeK Robert (1996): Die Wesensart der Oberschlesier bei Heinz Piontek. W: Schlesien nr 3: 171-175.

Buczek Robert (1998): Zum autobiographischen Werk von Heinz Piontek. W: Studia i Materiały. Germanistyka [Wyższa Szkoła Pedagogiczna im. Tadeusza Kotarbińskiego w Zielonej Górze] z. 14: 195-201.

BuczeK Robert (2002): Heinz Pionteks autobiographische Romane im Selbskreierungsprozess der eigenen Identität. W: MaŃCZYK Augustyn/ZIMnIAK Paweł/ Zuchewicz Tadeusz/BuczeK Robert (red.): Sinngebung. Zwischen Festlegung und Pluralität. Zielona Góra: Oficyna Wydawnicza Uniwersytetu Zielonogórskiego: 7-19.

BuczeK Robert (2003a): „Durch die Erinnerung wach sein...”. Nachruf auf Heinz Piontek. W: Oberschlesisches Jahrbuch Bd. 19: 308-309.

BuczeK Robert (2003b): Heinz Pionteks Suche nach seiner eigenen Identität in den Romanen „Zeit meines Lebens” und "Stunde der Überlebenden”. In: BiaŁek Edward/Buczek Robert/Zimniak Paweł (red.): Eine Provinz In der Literatur. Schlesien zwischen Wirklichkeit und Imagination. Wrocław, Zielona Góra: Oficyna Wydawnicza ATUT - Wrocławskie Wydawnictwo Oświatowe: $265-275$.

BuRAS Jacek S. (1996): Bibliographie deutscher Literatur in polnischer Übersetzung. Vom 16. Jahrhundert bis 1994. Wiesbaden: Harrassowitz [seria: Veröffentlichungen des Deutschen Polen-Instituts Darmstadt, Band 10].

DitTmar Peter (2003): „Ich lernte, dass man vor seinem Gedächtnis nie sicher ist”. Büchner-Preisträger Heinz Piontek gestorben/,Życie mnie nauczyło, że nigdy nie jest się bezpiecznym od własnej pamięci”. Heinz Piontek, laureat Nagrody Literackiej im. Büchnera, nie żyje. W: Joseph von Eichendorff Konversatorium. Zeszyty Edukacji Kulturalnej / Hefte für Kulturbildung nr 41: 138-143.

E.B. [= Bielicka Emilia] (1973): Piontek Heinz. W: Chodera Jan/Urbanowicz Mieczysław (red.): Mały słownik pisarzy niemieckich, austriackich i szwajcarskich. Warszawa: Wiedza Powszechna: 281. 
FeILert Emil (2003a): Auf den Kreuzburger Spuren Heinz Pionteks / Kluczborskie ślady Heinza Piontka. Tłum. Jan GoczoŁ. W: Joseph von Eichendorff Konversatorium. Zeszyty Edukacji Kulturalnej / Hefte für Kulturbildung nr 38: 32-55.

FEILERT Emil (2003b): Heinz Piontek. W: Zeszyty Eichendorffa / Eichendorff-Hefte nr 3: 50-59.

FIC Maciej (2007): Wilhelm Szewczyk (1916-1991). Ślaski polityk i działacz spoteczny. Katowice: Wydawnictwo Uniwersytetu Śląskiego.

Funrmann Horst (2004): Kluczbork Heinza Piontka. W: KüHnemann Adolf (red.): Heinz Piontek - życie i dzieło. Tłum. Jan GoczoŁ (proza) i Andrzej LAM (poezja). Opole: Konwersatorium im. Josepha von Eichendorffa: 147160.

HaAs Olaf/FeIlert Emil (2004): Heinz Piontek - biograficzne znaki przydrożne. W: Kühnemann Adolf (red.): Heinz Piontek - życie i dzieło. Tłum. Jan GoCzOŁ (proza) i Andrzej LAM (poezja). Opole: Konwersatorium im. Josepha von Eichendorffa: 175-180.

Hollender Martin (2000): Bibliographie Heinz Piontek. Bielefeld: Aisthesis-Verlag [Archivreihe der Stiftung Haus Oberschlesien, Band III].

Honsza Norbert (1970): Prady literackie w NRF. W: Wiadomości nr 31: 5.

HonszA Norbert (1974): Zur literarischen Situation nach 1945 in der BRD, in Österreich und in der Schweiz. Wrocław: Państwowe Wydawnictwo Naukowe.

Honsza Norbert (1975): Ksztatt i struktura. Literatura NRF, Austrii i Szwajcarii po roku 1945. Katowice: Śląsk.

Honsza Norbert (1976): Literatur der Gegenwart. BRD - Österreich - Schweiz. Wrocław: Wydawnictwa Uniwersytetu Wrocławskiego.

Honsza Norbert (1988): Kalejdoskop sukcesu: proza niemieckojęzyczna lat osiemdziesiątych. W: Życie Literackie nr 41: 1, 6-7.

Honsza Norbert (1994): Literatur als Provokation. Prowokacje literackie. Wrocław: Wydawnictwo Uniwersytetu Wrocławskiego.

Hryńczuk Jan (1975): Marian Szyrocki, Dzieje literatury niemieckiej. Podręcznik, t. II, Warszawa 1972. W: Germanica Wratislaviensia T. 21: 109-111.

Jarosz-Sienkiewicz Ewa (2013): Heinz Piontek, „Die Furt”. Zwischen dem Heute und dem Gestern. Auf der Suche nach treffendem Ausdruck. W: Studia Niemcoznawcze T. 52: 255-269.

Jarosz-Sienkiewicz Ewa (2015): Der „Indianersommer” von Heinz Piontek als Abbild der Haupttendenzen im Schaffen des Dichters. W: KIC-Drgas Joanna (red.): Literatur und Interkulturalität im Fremdsprachenunterricht am Anfang des 21. Jahrhunderts. Hamburg: Kovač Verlag: 27-41.

Jarosz-SiENKIEWICZ Ewa (2016): Landschaft als Ehrfahrung. Zum lyrischen Schaffen von Heinz Piontek. In: Gajdis Anna/Mańczyk-Krygiel Monika (Hg.): Der imaginierte Ort, der (un)bekannte Ort. Zur Darstellung des Raumes in der Literatur. Bern: Peter Lang: 295-308.

Jarosz-Sienkiewicz Ewa (2017): Heinz Pionteks Erzählungen “Vor Augen”. Zu einer subjektiven Wahrnehmung. In: BıAŁEK Edward/HuszczA Krzysztof (Hg.): Zwischen Breslau und Wien. Zu schlesisch-österreichischen Kulturbe- 
ziehungen in Geschichte und Gegenwart. Dresden: Neisse: 309-324; również w: Silesia Nova nr 1: 104-116.

Jens Walter (1961): Deutsche Literatur der Gegenwart. München: Piper.

KARST Roman (1966): Literatura niemiecka. W: Rocznik Literacki: 549-561.

KASzyŃski Stefan H. (1967): Ludzie doby kryzysu. W: Nurt nr 4: 52-53.

KASZYŃski Stefan H. (1977): Rozważania nad poezja NRF. W: Nurt nr 3: 20-23.

Koczy Karol (1978): Szkice z literatury niemieckiej. W: Odra nr 7/8: 137.

Koprowski Jan (1988): Antologia cytatów. W: Kierunki nr 13: 10.

Krysztofiak Maria (1975): Nieznany cel. W: Nurt nr 5: 40.

KuczyŃski Krzysztof A. (1981): Literatura Republiki Federalnej Niemiec w Polsce. Łódź: Uniwersytet Łódzki.

Kühnemann Adolf (2004): Słowo wstępne. W: Heinz Piontek - życie i dzieło. Tłum. Jan GoczoŁ (proza) i Andrzej LAM (poezja). Opole: Konwersatorium im. Josepha von Eichendorffa: 6.

Kühnemann Adolf (red.) (2004): Heinz Piontek - życie i dzieło. Tłum. Jan GoCzOŁ (proza) i Andrzej LAM (poezja). Opole: Konwersatorium im. Josepha von Eichendorffa.

LANGEnbuCHER Wolfgang R. (Hg.) (1966): Deutsche Erzählungen aus zwei Jahrzehnten. Herrenalb: Erdmann.

Lichański Stefan (red.) (1973): ...tu felix Austria... Antologia noweli austriackiej XX wieku. Warszawa: Państwowy Instytut Wydawniczy.

Lisowska Krystyna (1978): M. Szyrocki, N. Honsza, Szkice z literatury niemieckiej XX wieku, Wrocław 1978, Wydawnictwa Uniwersytetu Wrocławskiego, s. 234. W: Kwartalnik Opolski nr 4: 133-134.

Literatura świata. Encyklopedia PWN. Literatury narodowe, twórcy i dzieła, prady $i$ kierunki. Warszawa: Wydawnictwo Naukowe PWN 2007.

LotKo Marek (2005): Stan badań nad twórczościa literacka Heinza Piontka $w$ Polsce. W: Kwartalnik Opolski nr 2/3: 57-82.

Lubos Arno (1961): Die schlesische Dichtung im 20. Jh. München: Bergstadtverlag Korn.

MacıĄG Włodzimierz (1967): Miłość jako nieszczęście. W: Życie Literackie nr 5: 10.

Maślanka Julian (red.) (2005): Encyklopedia literatury światowej. Kraków: Zielona Sowa.

Maślanka Julian (red.) (2008): Słownik pisarzy świata. Kraków: Krakowskie Wydawnictwo Naukowe.

Matkowska Ewa/Polechoński Krzysztof/Rzeszotnik Jacek (2017): Literatura polska $w$ tajnych dokumentach NRD. Portrety $i$ szkice. Warszawa: Instytut Pamięci Narodowej - Komisja Ścigania Zbrodni przeciwko Narodowi Polskiemu.

MazursKa Ilona (1986): Literackie powroty. W: Tak i Nie. Ślask nr 3: 63-69.

Neunzehn deutsche Erzählungen. München: Nymphenburger Verlagshandlung 1963.

Odojewski Włodzimierz (1996): Na śmierć Horsta Bienka. W: Idem: Notatnik półprywatny: w kręgu kultury. Lublin: Wydawnictwo Uniwersytetu Marii Curie-Skłodowskiej: 153-154. 
OrŁowsKi Hubert (1967): Prawdziwy koniec wielkiej wojny? W: Miesięcznik Literacki nr 6: 122-123.

OrŁoWsKi Hubert (1972): Z germanistyki polskiej. W: Rocznik Literacki: 322-323.

OrŁowsKi Hubert (1976): Norbert Honsza, Zur literarischen Situation nach 1945 in der BRD, in Österreich und in der Schweiz, Wrocław 1974...; Norbert Honsza, Ksztatt i struktura. Literatura NRF, Austrii i Szwajcarii po roku 1945, Katowice 1975. W: Studia Historica Slavo-Germanica T. 5: 244-246.

PęDziński Zbigniew (1967): Wnieść światto $w$ mroczna historię. W: Litery nr 12: 32.

Piontek Heinz (1965a): Gorace kasztany. Tłum. Zofia Jaremko-Pytowska. Warszawa: Czytelnik.

Piontek Heinz (1965b): Posiłek robotników drogowych. Tłum. Florian Śmieja. W: Poglądy nr 19: 8.

Piontek Heinz (1966a): Klartext. Hamburg: Hoffmann \& Campe.

PIONTEK Heinz (1966b): Licht in eine dunkle Geschichte bringen. Interview mit sich selbst. W: Die Welt der Literatur nr 25: 14.

PionteK Heinz (1966c): Vergeßt uns. W: Christ und Welt nr 12: 37.

PIONTEK Heinz (1967): Posiłek robotników drogowych. Tłum. Florian ŚMIEJA. W: Oficyna Poetów nr 2: 32.

PIONTEK Heinz (1969a): Die Lyrik Zbigniew Herberts. W: Zeitwende nr 5: 334340.

PIONTEK Heinz (1969b): Gedichte von Tadeusz Różewicz. W: Neue Zürcher Zeitung nr 304: 57.

PionTeK Heinz (1969c): Różewicz auf sensiblen Wegen. Die Lyrik des Polen ist reifer und differenzierter geworden. W: Rheinischer Merkur nr 49: 34.

PionteK Heinz (1970a): Einziges Dogma: Menschlichkeit. Zur Lyrik Zbigniew Herberts. W: Wort und Wahrheit nr 2: 127-133.

PIONTEK Heinz (1970b): Neue Różewicz-Gedichte. W: Zeitwende 1970 T. 41: 337-339.

Piontek Heinz (1970c): Ostrożni. Tłum. Alfred KowalkowsKi. W: Poglądy nr 19: 15.

Piontek Heinz (1971a): Die Erzählungen. München, Wien: Langen Müller.

Piontek Heinz (1971b): Oderwane istnienie. Tłum. Stanisław Barańczak. W: Nurt nr 10: 28.

Piontek Heinz (1972): Rozproszeni, Bądź zdrów. Tłum. Lucjan Stosio. W: Literatura na Świecie nr 7: 110-112.

Piontek Heinz (1974a): Abseits der modischen Theorien. W: Neue Zürcher Zeitung nr 517: 66.

PionteK Heinz (1974b): Ein ironisches Ich. Zbigniew Herberts Lyrik am Wendepunkt. W: Rheinischer Merkur nr 47: 36.

Piontek Heinz (1975): Brat i brat. Tłum. Leonia Martyna GradsteIn. W: Zwierciadto nr 12: 11.

Piontek Heinz (1979): Chmury. Tłum. Bolesław Fac. W: Punkt nr 6: 94.

Piontek Heinz (1980): Obłoki. Tłum. Alfred Kowalkowski. W: Antochewicz Bernard/KarkowsKi Kazimierz/Karpowicz Tymoteusz/Szwed Leon (red.): 
Poezja XX wieku. Austria, NRD, RFN, Szwajcaria. Wrocław, Warszawa, Kraków, Gdańsk: Zakład Narodowy im. Ossolińskich: 404-405.

Piontek Heinz (red.) (1987): Jeder Satz ein Menschengesicht. Schriftsteller berichten über ihren Beruf. München: Piper.

Piontek Heinz (1990): Zdania proste z roku 1968. Tłum. Jakub EkiER. W: Res Publica nr 4: 74.

Piontex Heinz (2003a): Die verlorene Stadt / Miasto utracone, Aufgegeben vor langer Zeit / Rezygnacja. Tłum. Marcin Wiatr. W: Zeszyty Eichendorffa / Eichendorff-Hefte nr 4: 4-7.

Piontek Heinz (2003b): Oczekiwanie Bożego Narodzenia. W: Zeszyty Edukacji Kulturalnej / Hefte für Kulturbildung nr 37: 6-17.

Piontek Heinz (2004): Akademia Sztuk Pięknych. Tłum. Andrzej Lam. W: Borussia nr 33/34: 69.

Pluta Jerzy (1967): Heinz Piontek czyli rzetelna proza. W: Odra nr 1: 84-85.

Polechoński Krzysztof/Kunicki Wojciech (2015): Die Literatur der westlichen Besatzungszonen sowie die der Bundesrepublik Deutschland als Forschungsgegenstand der polnischen Germanistik 1945-1990. In: KunICKI Wojciech/ ZyвuRA Marek (Hg.): Geschichte der literaturwissenschaftlichen Germanistik in Polen. Band I: Inhalte und Methoden. Leipzig: Leipziger Universitätsverlag 2015: 105-169.

Programy ramowe i plany studiów: Filologia germańska. Warszawa: Państwowe Wydawnictwo Naukowe 1966.

RogalSKI Aleksander (1962): Niemiecka Republika Federalna. Fakty, konfrontacje, opinie. Poznań: Wydawnictwo Poznańskie.

SADKowski Wacław (1966): Trudno być pisarzem niemieckim. W: Trybuna Ludu nr 349: 4.

SADKOWski Wacław (1968): Drogi i rozdroża literatury Zachodu. Warszawa: Książka i Wiedza.

Schumann Renata (1997): Die verlorene Stadt. Das Bild Oberschlesiens im Schaffen von Heinz Piontek. In: Kroll Frank-Lothar (Hg.): Flucht und Vertreibung in der Literatur nach 1945. Berlin: Gebr. Mann: 67-86.

Schumann Renata (1998): Trauer um eine Stadt. In: Deutscher Ostdienst Nr. 7.

SŁUGocka Ludmiła (1968): Über die Grenzen hinaus. Deutsche Polenlyrik seit den Anfängen bis 1965. Warszawa: Państwowe Wydawnictwo Naukowe.

SŁugocka Ludmiła (1975): Powojenna zachodnioniemiecka liryka o Polsce $w$ świetle zaangażowania pisarzy. Poznań: Poznańskie Towarzystwo Przyjaciół Nauk.

SteINHERr Ludwig (2004): Wszechświat to tylko waskie drzwi. Na 75. urodziny Heinza Piontka $w$ dniu 15 listopada 2000 r. W: KüHnemann Adolf (red.): Heinz Piontek - życie $i$ dzieło. Tłum. Jan GoczoŁ (proza) i Andrzej Lam (poezja). Opole: Konwersatorium im. Josepha von Eichendorffa: 161-174.

Stroka Anna/Szyrocki Marian (1968): Deutsche Lyrik des 20. Jahrhunderts. Warszawa: Państwowe Wydawnictwo Naukowe.

Szewczyк Wilhelm (1961): Heinz Piontek, czyli objawienie talentu. W: Zaranie Śląskie z. 4: 810-818. 
SzEWCZYK Wilhelm (1962): Literatura niemiecka $w$ XX wieku. Katowice: Śląsk. SZEWCZYK Wilhelm (1963): The revanchist trend in West German fiction. In: Polish Western Affairs No. 1: 120-143.

SzeWCZyK Wilhelm (1966): Przez okulary z firmy Brauxel et Co. W: Życie Literackie nr 25: 3-4.

SzEWCZYK Wilhelm (1969): Okulary z firmy Brauxel \& Co. Szkice literackie. Łódź: Wydawnictwo Łódzkie.

SzEWCZYK Wilhelm (1986): Nostalgiczne powroty - dokad i po co? W: Trybuna Robotnicza nr 296: 5.

Szyrocki Marian (1963a): Historia literatury niemieckiej. Zarys. Wrocław: Zakład Narodowy im. Ossolińskich.

Szyrocki Marian (1963b): Literatura Niemiec Zachodnich. Kierunki i problemy. Katowice: Śląski Instytut Naukowy.

SzYrocki Marian (1963c): Wilhelm Szewczyk: Literatura niemiecka w XX wieku. Katowice 1962, Wydawnictwo „Śląsk”. W: Zaranie Śląskie z. 4: 694-696.

Szyrocki Marian (1971): Historia literatury niemieckiej. Zarys. Wrocław: Zakład Narodowy im. Ossolińskich.

Szyrocki Marian (1972): Dzieje literatury niemieckiej. T. 2. Warszawa: Państwowe Wydawnictwo Naukowe.

Szyrocki Marian (1975): Antologia opowiadań RFN. W: Nowe Książki nr 4: 11-12.

Szyrocki Marian/Honsza Norbert (1978): Szkice z literatury niemieckiej XX wieku. Wrocław: Wydawnictwa Uniwersytetu Wrocławskiego.

Śmieja Florian (1967): Heinz Piontek. W: Oficyna Poetów nr 2: 32.

Śmieja Florian (2012): Zapiski o świcie. Oprac. Jolanta Pasterska. Rzeszów: Wydawnictwo Uniwersytetu Rzeszowskiego.

Ubysz Andrzej (1978): Szkice z literatury. W: Poglady nr 8: 12.

Uniwersytety. Studia magisterskie (jednolite). Plany studiów i programy nauczania przedmiotów kierunkowych. Kierunek studiów: filologia germańska. Warszawa: Ministerstwo Nauki, Szkolnictwa Wyższego i Techniki 1974.

Wilczeк Stanisław (1978): Vier Generationen deutscher Schriftsteller aus Polen. W: Begegnung mit Polen nr 3: 17-23.

WISZ [= SzEWCZYK Wilhelm] (1960a): Literackie fetysze odwetowców [z cyklu „Co robią Niemcy”]. W: Życie Literackie nr 46: 2.

WISZ (1960b): Nowy laureat odwetowców [z cyklu „Notatki i utarczki”]. W: Trybuna Robotnicza nr 259: 3.

WISZ (1961): Trzej tłumacze [z cyklu „Co robią Niemcy”]. W: Życie Literackie nr 33: 3.

WISZ (1962a): Bobrowski urodzit się w Sarmacji [z cyklu „Co robią Niemcy”]. W: Życie Literackie nr 39: 3.

WISZ (1962b): Dlaczego literatura w NRD jest taka, jaka jest [z cyklu „Co robią Niemcy"]. W: Życie Literackie nr 40: 3.

WISZ (1962c): Poeta doctus [z cyklu „Co robią Niemcy”]. W: Życie Literackie nr 22: 3.

WISZ (1962d): W deszczu nagród [z cyklu „Co robią Niemcy”]. W: Życie Literackie nr 33: 3 . 
WISZ (1964): Pogranicze [z cyklu Co robia Niemcy]. W: Życie Literackie nr 28: 2.

WISZ (1965): Gdy wygnanie staje się idylla [z cyklu Co robia Niemcy]. W: Życie Literackie nr 35: 2.

WISZ (1967): Poetycki Drang nach Westen [z cyklu Co robia Niemcy]. W: Życie Literackie nr 23: 2.

Wokót antologii. Z dyskusji odbytej w dniu 21 III 1975 r. w redakcji „Literatury na Świecie" na temat antologii opowiadań pisarzy NRD, RFN i Austrii. W: Literatura na Świecie $1975 \mathrm{nr} 8$.

Zybura Marek (1996): Piontek Heinz. W: Zybura Marek (red.): Pisarze niemieckojęzyczni XX wieku. Leksykon encyklopedyczny PWN. Wrocław: Wydawnictwo Naukowe PWN: 250.

ŻABICKI Zbigniew (1967): Sztuka tylko dla bohaterów? W: Nowe Książki nr 1: 36-37.

\section{Źródła archiwalne}

Biblioteka Instytutu Filologit Germańskiej UWr, Spuścizna M. Szyrockiego: list Mariana Szyrockiego do redakcji Państwowego Instytutu Wydawniczego z 25 IV 1966 r., sygn. M 212.

\section{Na marginesie recepcji literatury RFN... Polski odbiór Heinza Piontka}

Streszczenie: Dla Heinza Piontka (1925-2003), niemieckiego pisarza pochodzącego ze Śląska, okres największego zainteresowania trwał od lat 50. do 80. XX stulecia. Po początkowych sukcesach, odnoszonych zwłaszcza w poezji, stawiano go pośród najciekawszych zjawisk w literaturze Republiki Federalnej Niemiec. Jednak pod koniec życia znalazł się na marginesie życia literackiego i stopniowo popadł w zapomnienie. Mimo że jego teksty były tłumaczone na wiele języków obcych, on sam nigdy nie został szerzej przyswojony w Polsce. Przez wiele dziesięcioleci jedyną książką Piontka wydaną w polskim przekładzie był tom opowiadań Gorace kasztany (1966). Artykuł przedstawia polską recepcję tego pisarza od jej początków w latach 60. XX wieku do chwili obecnej. Rozpoczęta obiecująco prezentacja tego twórcy w Polsce mieści rozproszone przeważnie $\mathrm{w}$ prasie oraz paru antologiach przekłady jego liryki i nielicznych utworów prozą, obejmując ponadto dotyczące go szkice, recenzje, artykuły, obecność w skryptach uniwersyteckich, podręcznikach historii literatury niemieckiej i słownikach pisarzy, a w ostatnich dekadach również poświęcone mu prace naukowe (w tym monografie książkowe) polskich germanistów.

Słowa kluczowe: recepcja literatury niemieckiej w Polsce, literatura niemiecka XX wieku, niemieccy pisarze ze Śląska po II wojnie światowej, Heinz Piontek 


\section{Am Rande der Rezeption der BRD-Literatur... Heinz Pionteks Werk in Polen}

Zusammenfassung: Für Heinz Piontek, den aus Schlesien stammenden deutschen Schriftsteller, dauerte die Periode der größten Popularität von den 50er bis zu den 80er Jahren des 20. Jahrhunderts. Nach seinen ersten Erfolgen, besonders im Bereich der Lyrik, zählte er zu den interessantesten Vertretern der BRD-Literatur. Gegen Ende seines Lebens geriet er jedoch an den Rand der literarischen Öffentlichkeit, ja in Vergessenheit. Obwohl er in viele Sprachen übersetzt wurde, war er einem breiteren Publikum in Polen nicht bekannt. Über mehrere Jahrzehnte blieb der Erzählband Kastanien aus dem Feuer sein einziges Buch in polnischer Übersetzung (Gorace kasztany, 1966). Der Artikel stellt die polnische Rezeption der Werke des Schriftstellers von ihren Anfängen in der 60er Jahren bis zur Gegenwart dar. Die zu Beginn vielversprechende Präsentation des Autors in Polen erfasst verstreute Veröffentlichungen seiner Gedichte und Prosa auf Polnisch (vor allem in Zeitschriften und Anthologien), Skizzen, Rezensionen und Artikel zu seinem Werk, Erwähnungen in didaktischen Materialien, Literaturgeschichten, Lexika sowie wissenschaftliche Arbeiten (darunter Monographien) polnischer Germanisten.

Schlagwörter: Rezeption der deutschen Literatur in Polen, deutsche Literatur im 20. Jahrhundert, deutsche Schriftsteller aus Schlesien nach dem Zweiten Weltkrieg, Heinz Piontek

\section{On the margins of the German literature reception... Polish reception of Heinz Piontek}

Summary: For Heinz Piontek (1925-2003), a German writer from Silesia, the period of greatest popularity lasted from the 1950s to the 1980s. After initial success, especially in poetry, he was placed among the most interesting phenomena in the literature of the Federal Republic of Germany. However, at the end of his life he found himself on the margins of literary life and gradually fell into oblivion. Although his texts were translated into many foreign languages, he himself was never widely known in Poland. For many decades, the only book by Piontek published in Polish translation was the volume of short stories Gorace Kasztany [Hot Chestnuts] (1966). The article presents the Polish reception of this writer from its beginnings in the 1960s to the present day. The promisingly launched presentation of the writer in Poland includes translations of his poetry and few works in prose, scattered mostly in the press and in a few anthologies. It also includes sketches, reviews, articles, his presence in university scripts, textbooks on the history of German literature and dictionaries of writers, and in recent decades also in academic works (including book monographs) by Polish Germanists.

Keywords: reception of German literature in Poland, German literature of the 20th century, German writers from Silesia after World War II, Heinz Piontek

Krzysztof Polechoński - doktor habilitowany, historyk literatury, pracownik Instytutu Filologii Polskiej Uniwersytetu Wrocławskiego. Opublikował monografie: Żywot człowieka uzbrojonego. Biografia, twórczość i legenda literacka Sergiusza Piaseckiego (2000), 
Pisarz w czasach wojny i emigracji. Ferdynand Goetel i jego twórczość w latach 19391960 (2012) oraz - wspólnie z Wojciechem Kunickim - dwutomowe studium recepcyjne i antologię tekstów Ernst Jünger w publicystyce i literaturze polskiej lat 1930-1998 (2000), a także - razem z Ewą Matkowską i Jackiem Rzeszotnikiem - Literaturę polską $w$ tajnych dokumentach NRD. Portrety i szkice (2017). Opracował książkowe wydania tekstów rozproszonych Sergiusza Piaseckiego i Utworów zebranych (2008) Eugeniusza Małaczewskiego. Współredaktor edycji Dzieł wybranych Ferdynanda Goetla. Współautor wstępów do wyborów pism Józefa Piłsudskiego (razem z Włodzimierzem Suleją; 1999, wznowienie 2003) oraz Kazimierza Sosnkowskiego (wespół z Jerzym Kirszakiem; 2009). Szkice, artykuły, recenzje, tłumaczenia z języka niemieckiego zamieszczał m.in. w „Arcanach”, „Kresach”, „Odrze”, „Frazie”, „Nowych Książkach”, „Stańczyku”, „Niepodległości”, „Orbis Linguarum”, „Pracach Literackich”, „Przeglądzie Zachodnim" oraz w tomach zbiorowych.

Krzysztof Polechoński, Dr. habil., Mitarbeiter am Institut für Polnische Philologie der Universität Wrocław. Buchveröffentlichungen: Żywot człowieka uzbrojonego. Biografia, twórczość i legenda literacka Sergiusza Piaseckiego (2000), Pisarz w czasach wojny i emigracji. Ferdynand Goetel i jego twórczość w latach 1939-1960 (2012) und - zusammen mit Wojciech Kunicki - die zweibändige Publikation mit einer Anthologie Ernst Jünger $w$ publicystyce $i$ literaturze polskiej lat 1930-1998 (2000), sowie - zusammen mit Ewa Matkowska und Jacek Rzeszotnik - Literatura polska w tajnych dokumentach NRD. Portrety i szkice (2017); Herausgeber der verstreuten Texte von Sergiusz Piasecki und der gesammelten Werke von Eugeniusz Małaczewski, Utwory zebrane (2008); Mitherausgeber der ausgewählten Werke von Ferdynand Goetel; Mitautor der Vorworte zu den ausgewählten Schriften von Józef Piłsudski (zusammen mit Włodzimierz Suleja, 1999, Neuauflage 2003) und von Kaziemierz Sosnkowski (zusammen mit Jerzy Kirszak, 2009); Skizzen, Artikel, Rezensionen, Übersetzungen aus dem Deutschen in den Zeitschriften “Arcana”, “Kresy”, “Odra”, “Fraza”, “Nowe Książki”, “Stańczyk”, "Niepodległość", "Orbis Linguarum”, "Prace Literackie”, "Przegląd Zachodni” sowie in Sammelbänden. 